\title{
MIDDLE-UPPER DEVONIAN MIOSPORES FROM THE GHADAMIS BASIN (TUNISIA-LIBYA): SYSTEMATICS AND STRATIGRAPHY
}

\author{
STANISLAS LOBOZIAK ${ }^{1}$ and MAURICE STREEL ${ }^{2}$
}

${ }^{1}$ Laboratoire de Paléobotanique et Stratigraphie du Paléozoique, GRECO 7 du CRNS, Université des Sciences et techniques de Lille, Flandres-Artois, F-59655 Villeneuve d'Ascq (France)

${ }^{2}$ Paléobotanique et paléopalynologie, Université de l'Etat, Place du vingt-août, 7, B-4000 Liège (Belgium)

(Received November 30, 1987; revised and accepted May 9, 1988)

\begin{abstract}
Loboziak, S. and Streel, M., 1989. Middle-Upper Devonian Miospores from the Ghadamis Basin (Tunisia-Libya): Systematics and stratigraphy. Rev. Palaeobot. Palynol., 58: 173-196.

Fifty-five miospores (including 7 new species and 3 new combinations) that range from Emsian to late Frasnian are identified, and 48 illustrated from 4 boreholes in the Ghadamis Basin. Their stratigraphic distribution is given and correlations made with established chronostratigraphic schemes. The Old Red Sandstone Continent miospore zonation can obviously be applied to this part of the Gondwanaland. The similarity of the miospore assemblages in both continents since at least the Emsian, suggests a close proximity of these continents during the Middle and Upper Devonian.
\end{abstract}

\section{Introduction}

Recent works in northeast Libya (Paris et al., 1985; Streel et al., 1988) have shown that the first occurrence of many of the characteristic species of the miospore zonations recently developed in the Old Red Sandstone Continent (Richardson and McGregor, 1986), particularly in the Ardenne-Rhenish regions (Streel et al., 1987) are observed in the same sequence on the northern border of Gondwanaland. Therefore, unless accurate faunas provide contradictory data, there is no reason not to apply these biostratigraphies to correlations between the two palaeocontinents.

Accepting as a first step the identifications of miospores provided so far in western Libya (Massa and Moreau-Benoit, 1976; 1985; Moreau-Benoit, 1979; 1980; 1984), Streel et al. (1988, table I) have challenged their stratigraphic interpretation, restricting to the Eifelian Stage the palynozones 4-6, previously dated as Eifelian to the Upper Givetian, and to the early Givetian, the palynozones 7 and 8 , previously dated as Frasnian by Massa and MoreauBenoit, 1976.

As these late dates were used in recent North African palynological contributions (Abdesselam-Rouighi, 1986; Schrank 1987, and others), we wanted to study Ghadamis Basin material to compare it with the preliminary works in north-eastern Libya. D. Massa who has worked on the Palaeozoic of western Libya for many years had provided us (M.S.) with core samples of supposed Upper Silurian to Upper Devonian age. He had received permission to mention in his own publications the names of the boreholes and the depths of samples. We want to thank him very much for kindly extending these data to us.

The present paper will concern the systematic results on the more important taxa en- 
countered in this material and the stratigraphic consequences when they are compared with the Old Red Sandstone Continent zonations. Lateral correlations in Gondwanaland will be discussed in a later contribution.

\section{Material studied}

The map (Fig.1) locates the boreholes sampled. Borehole A1-69, drilled by SHELL in 1959 $\left(x=29^{\circ} 03^{\prime} 50^{\prime \prime}, y=13^{\circ} 40^{\prime} 13^{\prime \prime}\right)$ will constitute, by the exceptional amount of cores available, our main reference. It is here studied between $2103 \mathrm{ft}(641 \mathrm{~m})$ and $650 \mathrm{ft}(198 \mathrm{~m})$, giving 33 productive samples. Three other boreholes where cores are much more rare were also sampled. They are D1-26: $7999 \mathrm{ft}(2440 \mathrm{~m}), \mathrm{C} 1$ 49: $1170 \mathrm{~m}$ and MG1: $2221 \mathrm{~m}, 2232.6 \mathrm{~m}$ and $2234 \mathrm{~m}$. The electric logs available for borehole A1-69 are too poor to allow any correlations with the corresponding Awaynat Wanin Formations (D. Massa, pers. commun., 1987). Samples from borehole MG1, which is located on the Tunisian side of the Tunisian/Libyan border, and borehole C1-49 are all in Awaynat
Wanin Formations II and III, supposed to belong to the Givetian and Frasnian Stages. Accurate faunal data are not yet available.

On the same map (Fig.1) is also located the MOBIL boreholes studied by Moreau-Benoit, 1984 and Massa and Moreau-Benoit, 1985. The material studied by Massa and Moreau-Benoit, 1976 and Moreau-Benoit, 1979 and 1980 were all the samples available from about thirty boreholes aggregated in two composite sections, one for northern Tripolitania, one for southern Tripolitania and Fezzan, both in the Ghadamis Basin. The detailed location of these samples is not yet available (D. Massa, pers. commun., 1987).

\section{Systematics}

In most samples, miospores are very abundant, diversified and in a very good state of preservation. We have though that it was not necessary for the purpose of this paper to provide a complete analysis of all observed taxa. On the contrary, we have given some priority to the characteristic species of the Old

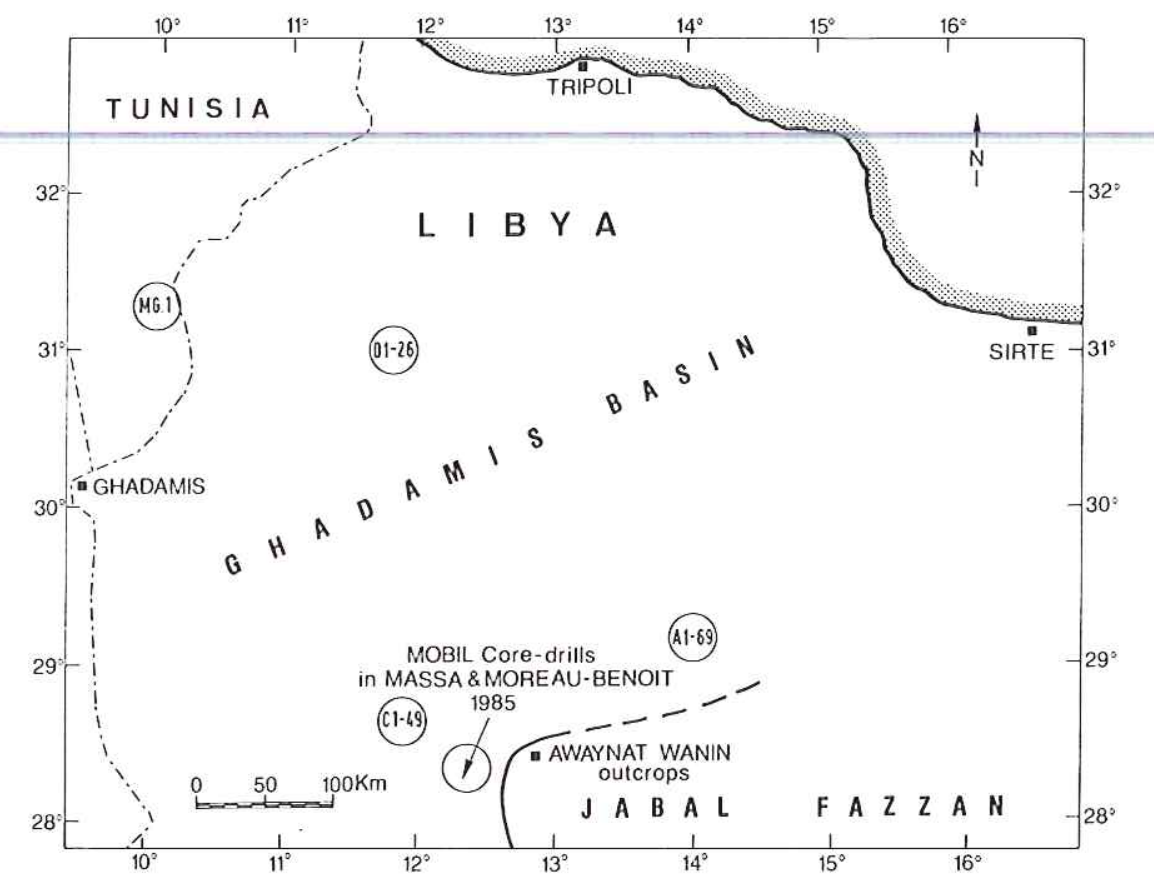

Fig.1. Location map of boreholes investigated in this paper. 
Red Sandstone Continent biozonation. However, we have also focused our attention on several frequent taxa restricted to the northern margin of Gondwanaland whose narrow stratigraphic range enhances the local biozonation.

Reference slides are stored in the Paleobotanical laboratory of the Université des Sciences et Techniques de Lille, à Villeneuve d'Ascq, France.

Letters and numbers following the slide numbers are England Finder numbers.

Species are listed below in alphabetic order of genera.

\section{Genus Acinosporites Richardson 1965}

Acinosporites acanthomammillatus Richardson 1965 (Plate I, 4)

Acinosporites apiculatus (Streel) Streel 1967 (Plate I, 3)

Acinosporites lindlarensis Riegel 1968 (Plate II, 5,6)

Acinosporites macrospinosus Richardson 1965

Genus Ancyrospora Richardson 1960 emend. Richardson 1962

Ancyrospora langii (Taugourdeau-Lantz) Allen 1965 (Plate VIII, 2)

Ancyrospora nettersheimensis Riegel 1973 (Plate VIII, 1)

Genus Archaeozonotriletes Naumova 1953 emend. Allen 1965

Archaeozonotriletes variabilis (Naumova) Allen 1965 (Plate I, 19)

Genus Auroraspora Hoffmeister, Staplin and Malloy 1955 emend. Richardson 1960

Auroraspora hyalina (Naumova) Streel in Becker et al., 1974 (Plate III, 3)
Genus Camarozonotriletes Naumova 1939 ex Ishchenko 1952

Camarozonotriletes sextantii McGregor and Camfield 1976 (Plate I, 11, 12)

Camarozonotriletes? concavus sp. nov. (Plate I, 13-15)

Holotype: Plate I, 14, borehole A1-69, slide 1483(1) : D31.

Diagnosis: Trilete cingulate miospores with subtriangular amb, rounded corners and concave to almost straight, interradial margins. Laesura arms simple, straight, reaching the cingulum. Cingulum, 2-6 $\mu \mathrm{m}$ wide, slightly reduced at corners, slightly darker than central area of the spore. Exine proximally laevigate, equatorially and distally microgranulate. Sculptural elements less than $1 \mu \mathrm{m}$ wide and high, closely spaced.

Diameter: $31-47 \mu \mathrm{m}$, mean $=38 \mu \mathrm{m}$ (28 specimens).

Derivation of name: Related to the concave interradial margins.

Remarks: In most cases, two slightly separated walls can be detected. Reduction of the cingulum width at corners is not often very conspicuous in this species and attribution to Camarozonotriletes is therefore questionable.

Comparison: Amongst sculptured species, $C$. antiquus Kedo 1955 has convex interradial margins. C. parvus Owens 1971 has a dark proximal area along trilete rays. C. pusillus Naumova ex Chibrikova 1959 has ornamentation elements up to $1.5 \mu \mathrm{m}$ high. C. sextantii McGregor and Camfield 1976 has higher and different sculpture.

Occurrence: $\mathrm{AD}$ pre Lem Zone= Eifelian.

Genus Chelinospora Allen 1965

Chelinospora concinna Allen 1965

Chelinospora (Archaeozonotriletes) timanica (Naumova) comb. nov. (Plate II, 8, 9)

Basionym : Archaeozonotriletes timanicus Naumova 1953, Trans. Inst. Geol. Sc. Acad. Sc. USSR, 143: p.81, pl.XII, fig.4. 
PLATE I
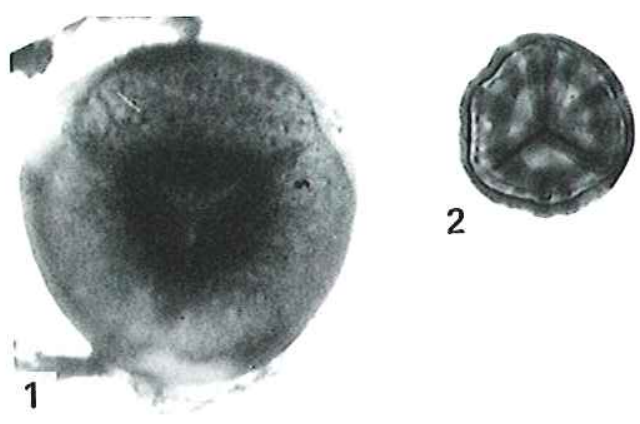

3
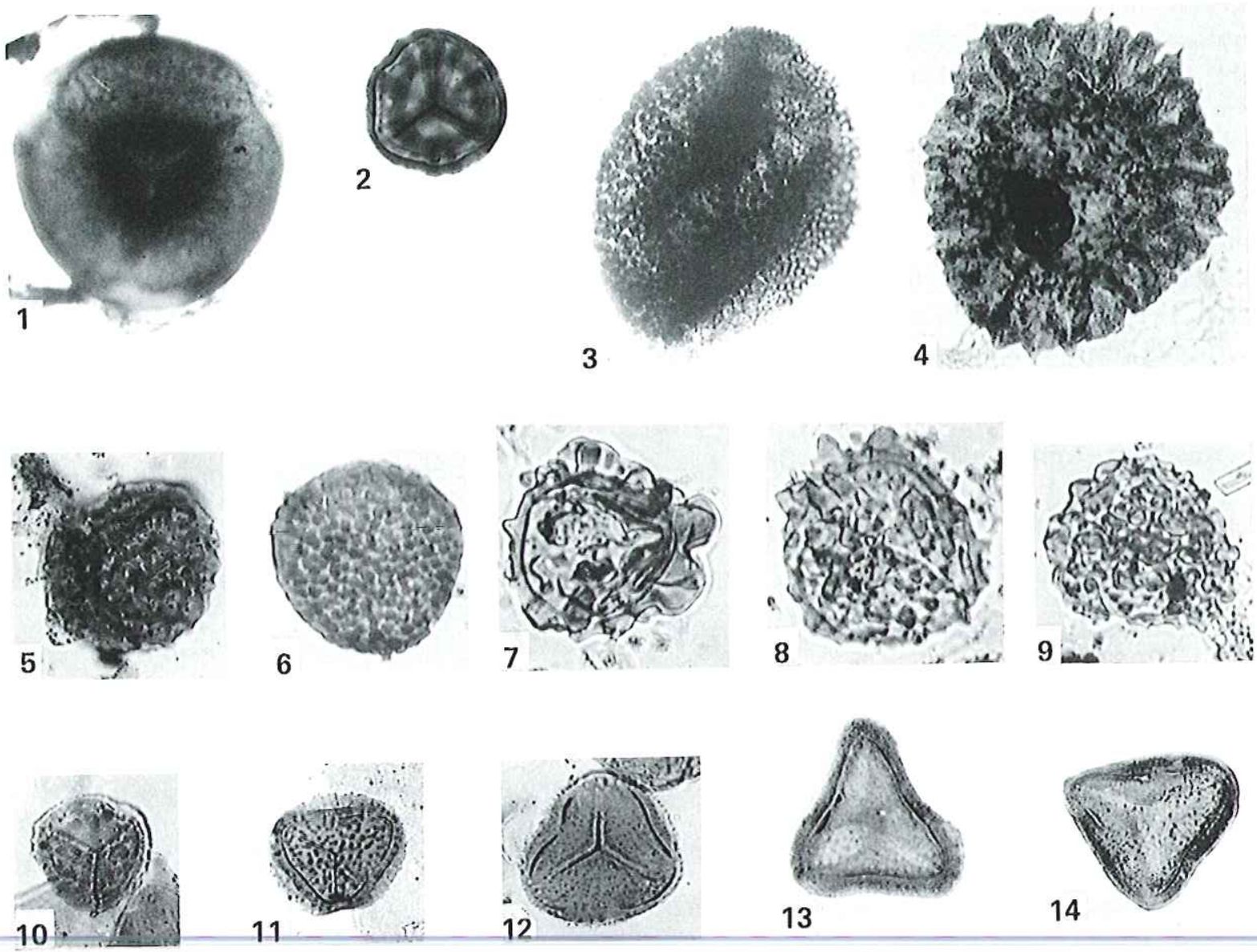
13
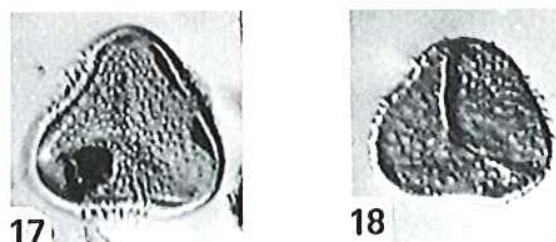

18
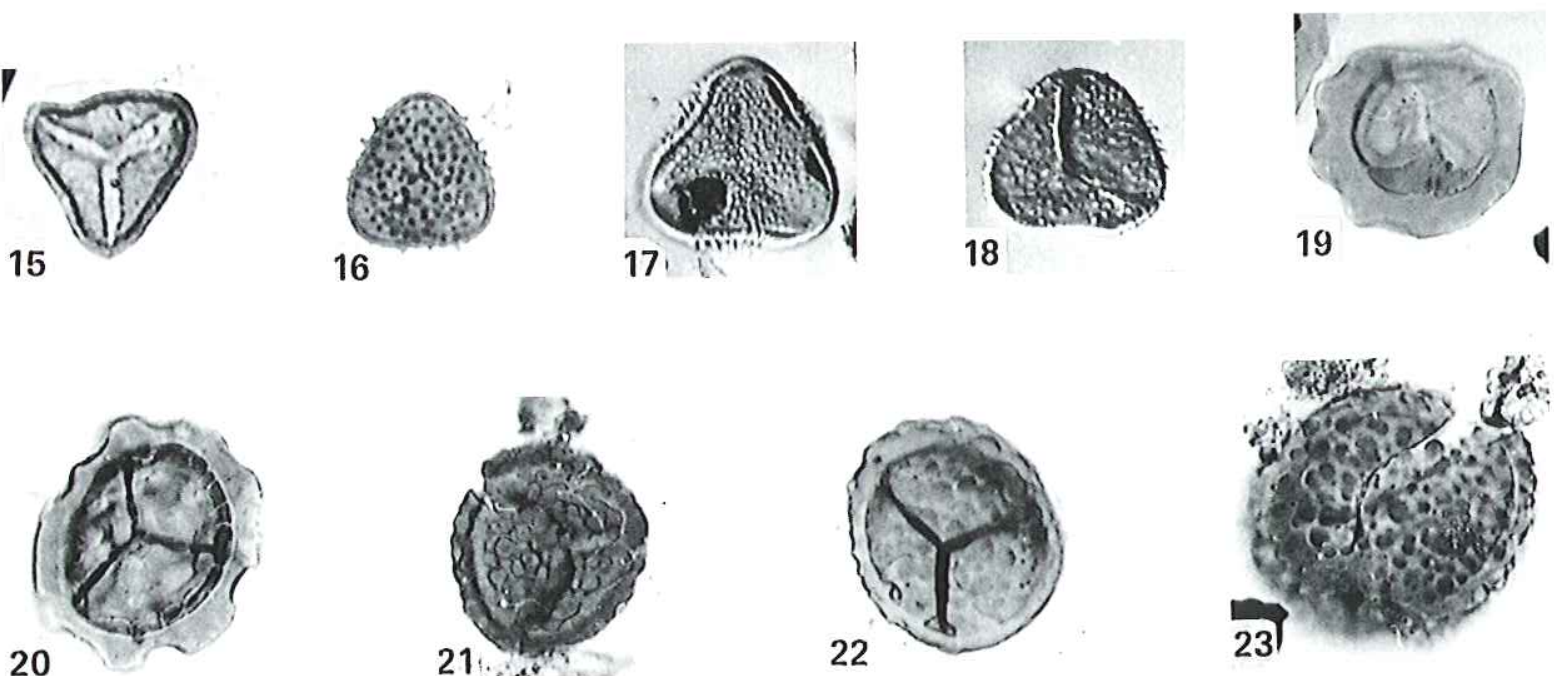
Remarks: The species of Archaeozonotriletes (Naumova) Allen 1965 are smooth. Ch. timanica is distally murornate.

\section{Genus Convolutispora Hoffmeister, Sta- plin and Malloy 1955}

Convolutispora disparalis Allen 1965 (Plate I, 5)

\section{Genus Corystisporites Richardson 1965}

Corystisporites multispinosus Richardson 1965 (Plate II, 7)

\section{Genus Craspedispora Allen 1965}

Craspedispora ghadamisensis sp. nov. (Plate II, 1-4, Plate IX, 4)
Holotype: Plate II, 1 and Plate IX, 4, borehole A1-69, slide 1700(1): W24 ${ }^{1}$.

Diagnosis: Trilete zonate miospores with subcircular to roundly triangular amb. Laesura arms slightly sinuous, up to $6 \mu \mathrm{m}$ high, almost reaching the equator. Proximal exine often microfolded, sometimes slightly thicker in the central area. Zona, including spines, up to $10 \mu \mathrm{m}$ wide interradially, distinctly narrower or absent radially, if present radially may be deflected onto the proximal face. Proximal surface laevigate. Distal surface and zona bearing biform ornaments: thin $(1 \mu \mathrm{m})$, elongated (up to $4 \mu \mathrm{m}$ ) spines on broad bases (up to $4 \mu \mathrm{m}$ diameter).

Diameter: $70-95 \mu \mathrm{m}$, mean $=80 \mu \mathrm{m}$ (30 specimens)

Derivation of name: after the locality of Ghadamis in Libya.

\section{PLATE I}

All photographs $\times 500$

1. Retusotriletes rugulatus Riegel 1973

$\mathrm{A}_{1}-69$, slide 1700 (1): $\mathrm{H}_{2} 9^{3}$.

2. Emphanisporites annulatus McGregor 1961 $\mathrm{C}_{1} \cdot 49$, slide $2753(1)$ : Q27.

3. Acinosporites apiculatus (Streel) Streel 1967

$\mathrm{A}_{1}-69$, slide $1700(1): \mathrm{E}^{3} 4^{3}$.

4. Acinosporites acanthomammillatus Richardson 1965

$\mathrm{A}_{1} \cdot 69$, slide 1483(1) : U37.

5. Convolutispora disparalis Allen 1965

$\mathrm{A}_{1} \cdot 69$, slide 1074(1): F29.

6. Verrucosisporites bulliferus Richardson and McGregor 1986 $\mathrm{D}_{1}-26$, slide 2764(2): V34 ${ }^{2}$.

7. Verrucosisporites premnus Richardson 1965 $\mathrm{MG}_{1}$, slide 2761(1): G36.

8, 9. Verrucosisporites scurrus McGregor and Camfield 1982 8, $\mathrm{MG}_{1}$, slide 2761(1) : Q37 $3.9, \mathrm{MG}_{1}$, slide 2761(1): U39.

10. Synorisporites libycus Richardson and Ioannides 1973

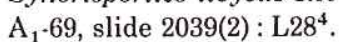

11, 12. Camarozonotriletes sextantii McGregor and Camfield 1976 11, $\mathrm{A}_{1} \cdot 69$, slide 2039(1): J32 ${ }^{3} .12, \mathrm{~A}_{1}-69$, slide 2039(1): N394

13-15. Camarozonotriletes? concavus nov. sp. $13, \mathrm{~A}_{1}-69$, slide $1486(1): \mathrm{X}^{1}$. 14, Holotype, $\mathrm{A}_{1} \cdot 69$, slide 1483(1) : D31. 15, A 1 -69, slide 1483(1) : L53 ${ }^{3}$.

16-18. Diatomozonotriletes franklinii McGregor and Camfield 1982 16, $\mathrm{C}_{1} \cdot 49$, slide 2753(1): W31. $17, \mathrm{MG}_{1}$, slide 2760(1): N25. $18, \mathrm{C}_{1} \cdot 49$, slide 2753(1) : T27 ${ }^{3}$.

19. Archaeozonotriletes variabilis (Naumova) Allen 1965 $\mathrm{MG}_{1}$, slide 2760(1) : G39.

20. Lophozonotriletes media Taugourdeau-Lantz 1967 $\mathrm{A}_{1}-69$, slide $976(1)$ : $\mathrm{H}_{3} 8^{2}$.

21-23. Lophozonotriletes bouckaertii nov. sp. 21, $\mathrm{A}_{1} \cdot 69$, slide 650(2): K30 $30^{3}$ 22, Holotype. $\mathrm{A}_{1} \cdot 69$, slide 650(1): Q33 ${ }^{3} .23, \mathrm{~A}_{1} \cdot 69$, slide 650(1) : Q40 ${ }^{1}$. 


\section{PLATE II}
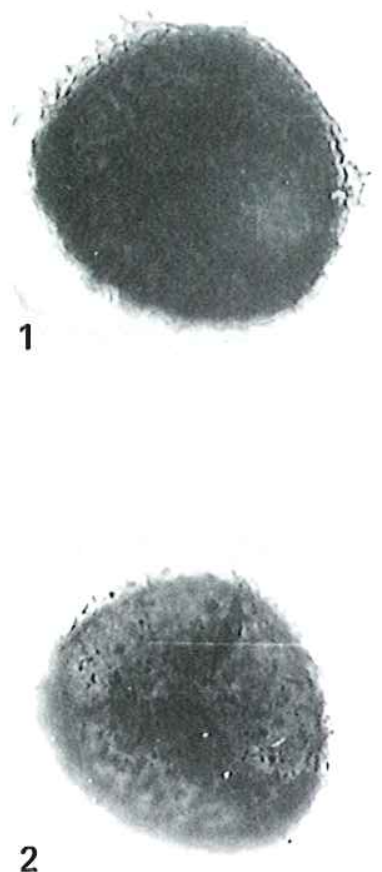

\section{2}
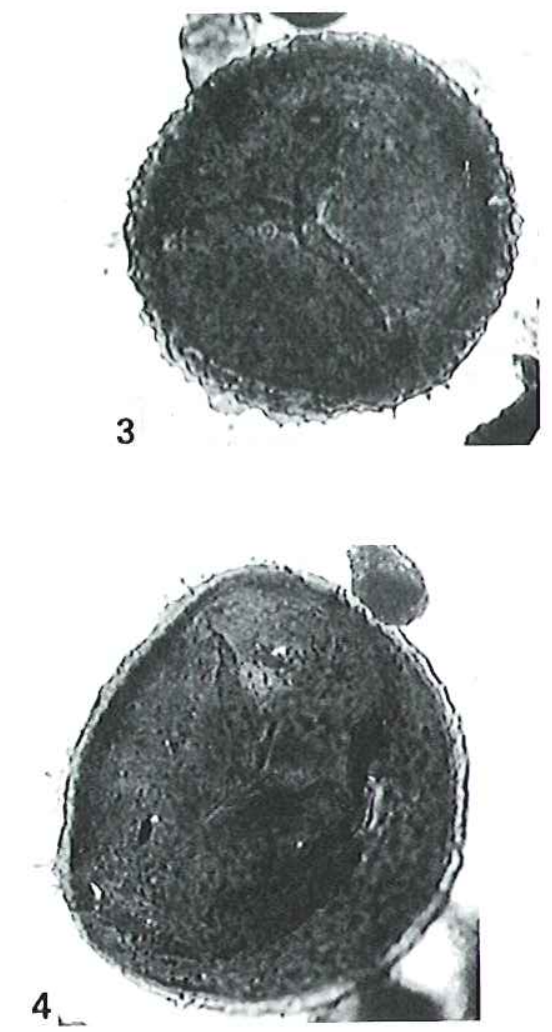
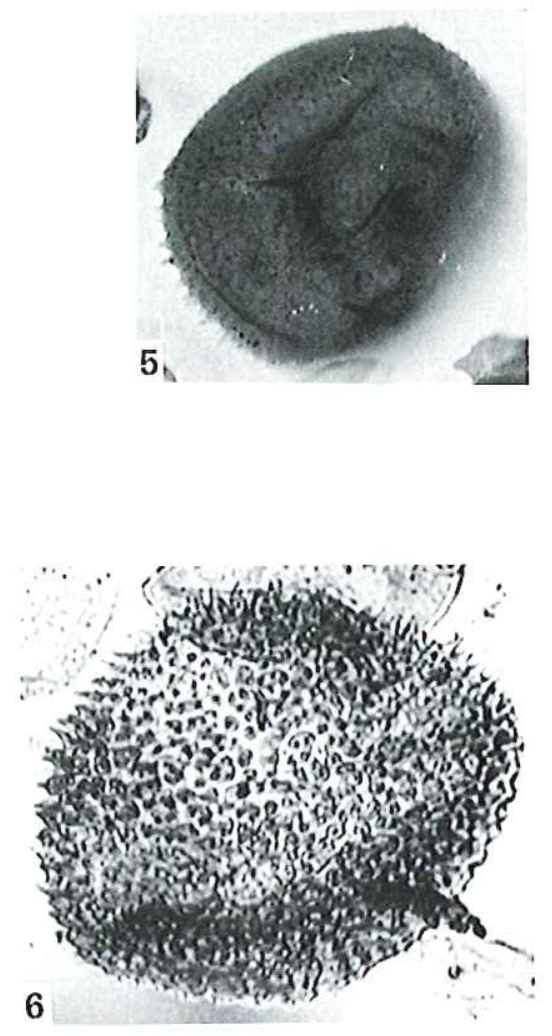

downsys
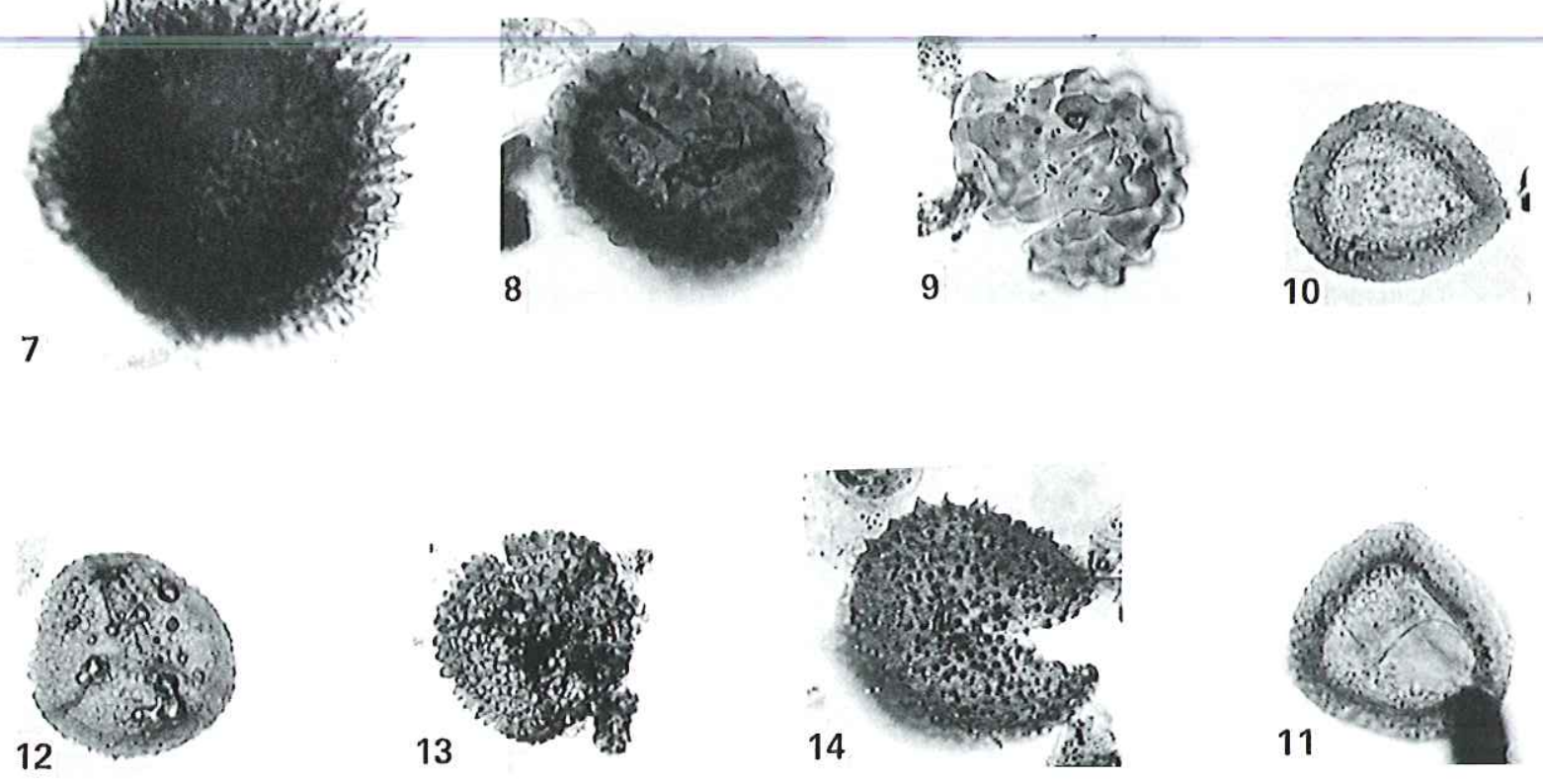
Comparison: Craspedispora craspeda Allen 1965 is smaller and has a laevigate or sparsely sculptured zona. C. arctica McGregor and Camfield 1982 is also smaller and has smaller different ornaments.

Occurrence: $\mathrm{AD}$ pre Lem to TA Zones= Eifelian to Givetian.

\section{Genus Cymbosporites Allen 1965}

Cymbosporites catillus Allen 1965 (Plate II, 10, 11 and Plate IX, 2)

Cymbosporites cyathus Allen 1965 (Plate II, 12-13 and Plate IX, 3)

Cymbosporites sp. (Plate II, 14)

Genus Densosporites Berry 1937 emend. Potonié and Kremp 1954

Densosporites devonicus Richardson 1960 (Plate IV, 11, 12)

\section{Genus Diatomozonotriletes Naumova 1939} emend. Playford 1963

Diatomozonotriletes franklinii McGregor and Camfield 1982 (Plate I, 16-18)

Remarks: We have observed a large variation in shape and size of ornaments which may vary from coni ( $1 \mu \mathrm{m}$ high) to spinae (up to $4 \mu \mathrm{m}$ high), encompassing the limit between $D$. franklinii and D. oligodontus Chibrikova 1962. However, the last species is claimed by Chibrikova to have variably developed curvaturae perfectae, a feature that we have not observed in our material.

\section{Genus Emphanisporites McGregor 1961}

Emphanisporites annulatus McGregor 1961 (Plate I, 2)

Emphanisporites rotatus McGregor 1961

Genus Geminospora Balme 1962 emend. Playford 1983

Geminospora lemurata Balme 1962 emend. Playford 1983 (Plate III, 7, 8, 11-15)

Geminospora punctata Owens 1971 (Plate III, 9, $10,16-18)$

Remarks: The surface of the exoexine possesses fine, densely distributed punctuations (Plate III, 16-18). However, we have only exceptionally noticed the fine radial striations which correspond, according to Owens (1971, p.62) to punctations passing completely through the exoexine.

\section{PLATE II}

All photographs $\times 500$

1-4. Craspedispora ghadamisensis nov. sp. 1, 2, Holotype, $A_{1} \cdot 69$, slide $1700(1): W 24^{1}$. 3, $A_{1} \cdot 69$, slide 1700(1):028. 4, $A_{1} \cdot 69$, slide $1700(1): 035^{3}$.

5, 6. Acinosporites lindlarensis Riegel 1968 5, $\mathrm{A}_{1} \cdot 69$, slide $2039(2): \mathrm{R}^{4}$. $6, \mathrm{~A}_{1} \cdot 69$, slide $2039(1): \mathrm{E} 40$.

7. Corystisporites multispinosus Richardson 1965 $\mathrm{A}_{1} \cdot 69$, slide $1700(1): \mathrm{F} 45^{3}$.

8, 9. Chelinospora timanica (Naumova) nov. comb. 8, $\mathrm{A}_{1} \cdot 69$, slide $1416(1): \mathrm{H} 36^{3} .9, \mathrm{~A}_{1}-69$, slide $650(1): \mathrm{H} 21$.

10, 11. Cymbosporites catillus Allen 1965 10, $\mathrm{A}_{1} \cdot 69$, slide 976(1): H29 ${ }^{3} .11, \mathrm{~A}_{1} \cdot 69$, slide 976(1): S41.

12, 13. Cymbosporites cyathus Allen 1965 12, $\mathrm{A}_{1}-69$, slide 650(2): L33. 13, $\mathrm{A}_{1} \cdot 69$, slide 650(1): $\mathrm{Q} 38^{3}$.

14. Cymbosporites sp. $\mathrm{A}_{1} \cdot 69$, slide $650(1): \mathrm{L} 33^{4}$. 
PLATE III
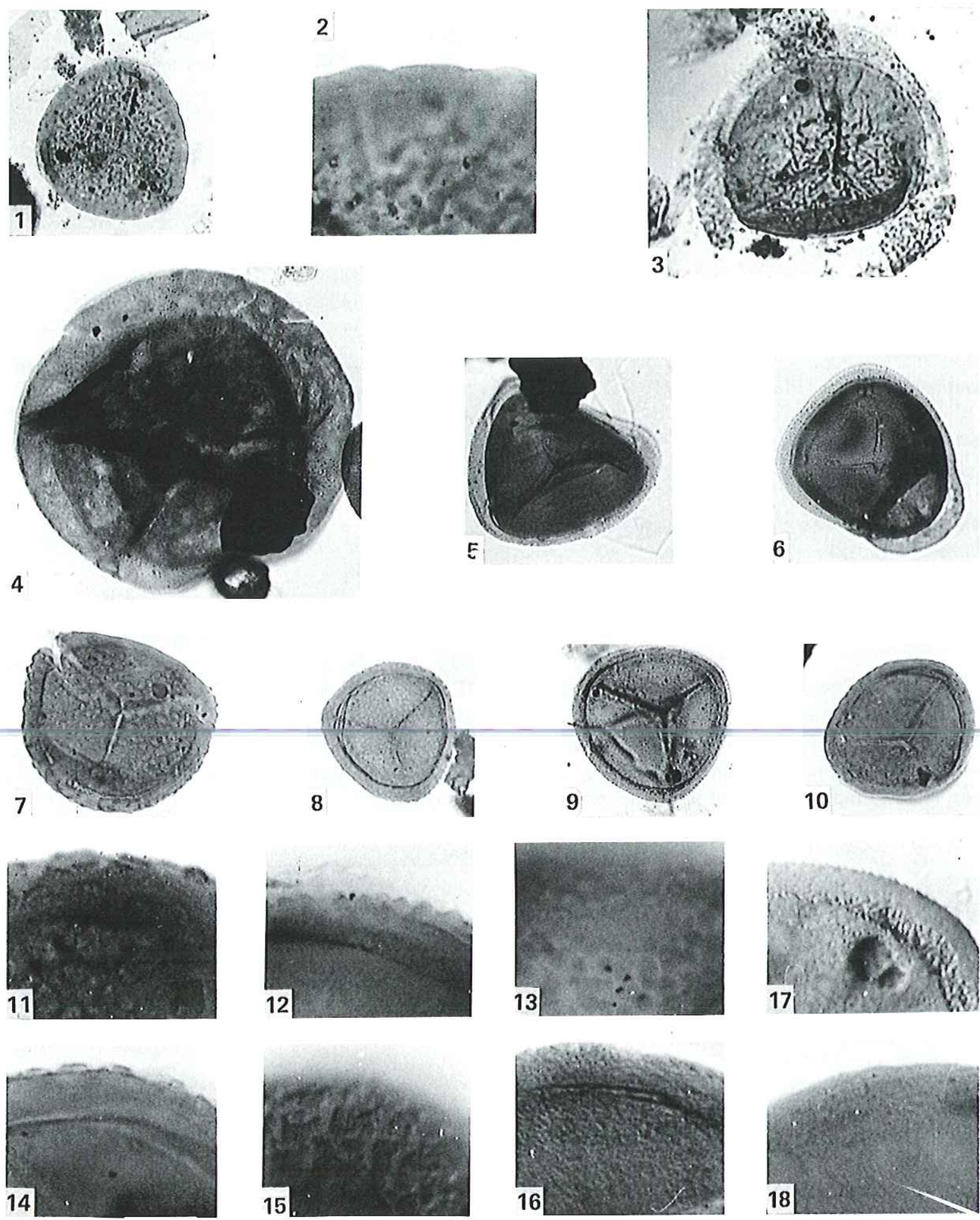
Genus Grandispora Hoffmeister, Staplin and Malloy 1955 emend. Neves and Owens 1966, as restated by Playford 1971

Grandispora cassidea (Owens 1971) MoreauBenoit 1976 (Plate VI, 1 and Plate IX, 26)

Grandispora douglastownense McGregor 1973 (Plate VII, 5 and Plate IX, 27)

Grandispora gabesensis sp. nov. (Plate VI, 2-4 and Plate IX, 17-20)

Holotype: Plate VI, 2 and Plate IX, 18, borehole A1-69, slide 1596(1): X30 ${ }^{1}$.

Diagnosis: Trilete, camerate miospores with subtriangular to roundly triangular amb. Intexinal body conformable to the exoexinal amb. Laesura arms, straight, up to $4 \mu \mathrm{m}$ high, usually reaching the equator. Intexine laevigate, sometimes with arcuate folds near the margin. Exoexine thinner than intexine, laevigate in contact areas, sculptured proximoequatorially and distally with coni, spinae, capilli and biform elements, 3-6 $\mu \mathrm{m}$ high, $0.5-2 \mu \mathrm{m}$ wide, irregularly spaced.

Diameter: $70-120 \mu \mathrm{m}$, mean $97 \mu \mathrm{m}$ (17 specimens).

Diameter of intexinal body: $62-85 \%$ (commonly $77 \%$ ) of total spore diameter.

Derivation of name: After the Libyan harbour of Gabes.
Comparison: Grandispora inculta and G. riegelii have smaller different ornaments. Other Devonian and Lower Carboniferous spinose Grandispora have more widely spaced ornaments.

Occurrence: $\mathrm{AD}$ pre Lem Zone=Eifelian.

Grandispora incognita (Kedo) McGregor and Camfield 1976 (Plate VII, 1 and Plate IX, 24)

Grandispora inculta Allen 1965 (Plate V, 6, 7 and Plate IX, 14, 15)

Remarks: Expanded diagnosis of this species by McGregor and Camfield 1982, p.45 might include some of the specimens here assigned to Grandispora riegelii nov. sp. (see diagnosis below). We propose to limit the $G$. inculta concept to specimens where the distances between the ornaments are at least equal to their basal diameter.

Grandispora libyensis Moreau-Benoit 1980 (Plate VII, 3 and Plate IX, 25)

Remarks: The holotype of $G$. libyensis was first described as Spinozonotriletes echinatus Moreau-Benoit 1967 in the "Schistes bleus (Siegenien moyen)" from Anjou in France. The presence of this-species and of many other large camerate spores in this formation is not compatible with the present knowledge of

\section{PLATE III}

All photographs $\times 500$, except where otherwise stated

1, $2 . \quad$ Rugospora bricei nov. sp.

1, Holotype, $\mathrm{A}_{1} \cdot 69$, slide $650(1)$ : Q38 $8^{3}$. 2, Detail of the fig. $1, \times 1800$.

3. Auroraspora hyalina (Naumova) Streel in Becker et al., 1974

$\mathrm{A}_{1} \cdot 69$, slide $650(2): \mathrm{L}_{2} 8^{2}$.

4. Rhabdosporites langii (Eisenack) Richardson 1960

$\mathrm{A}_{1} \cdot 69$, slide $1416(1): \mathrm{E}^{4} 5^{4}$.

5, 6. Rhabdosporites minutus Tiwari and Schaarschmidt 1975

$5, A_{1} \cdot 69$, slide $1530(1):$ M53. $6, A_{1} \cdot 69$, slide $1700(1): U 43^{2}$.

7, 8, 11-15. Geminospora lemurata (Balme 1962) emend. Playford 1983

$7, A_{1} \cdot 69$, slide $1322(1): F 40.8, A_{1} \cdot 69$, slide $1322(1): W 42^{4} .11$, Detail of the fig. $7 \times 1800.12,13, A_{1} \cdot 69$, slide 1322(1): W38 ${ }^{2}, \times 1800.14,15, \mathrm{~A}_{1} \cdot 69$, slide $1322(1): \mathrm{L}^{1} 9^{1}, \times 1800$.

9, 10, 16-18. Geminospora punctata Owens 1971

$9, \mathrm{~A}_{1}-69$, slide $650(2): \mathrm{H} 27^{1} .10, \mathrm{~A}_{1}-69$, slide $1322(1):$ N50. $16, \mathrm{~A}_{1}-69$, slide $1322(1): \mathrm{F} 52^{3}, \times 1800.17$, Detail of the fig. $9, \times 1800.18$, Detail of the fig. $10, \times 1800$. 
PLATE IV
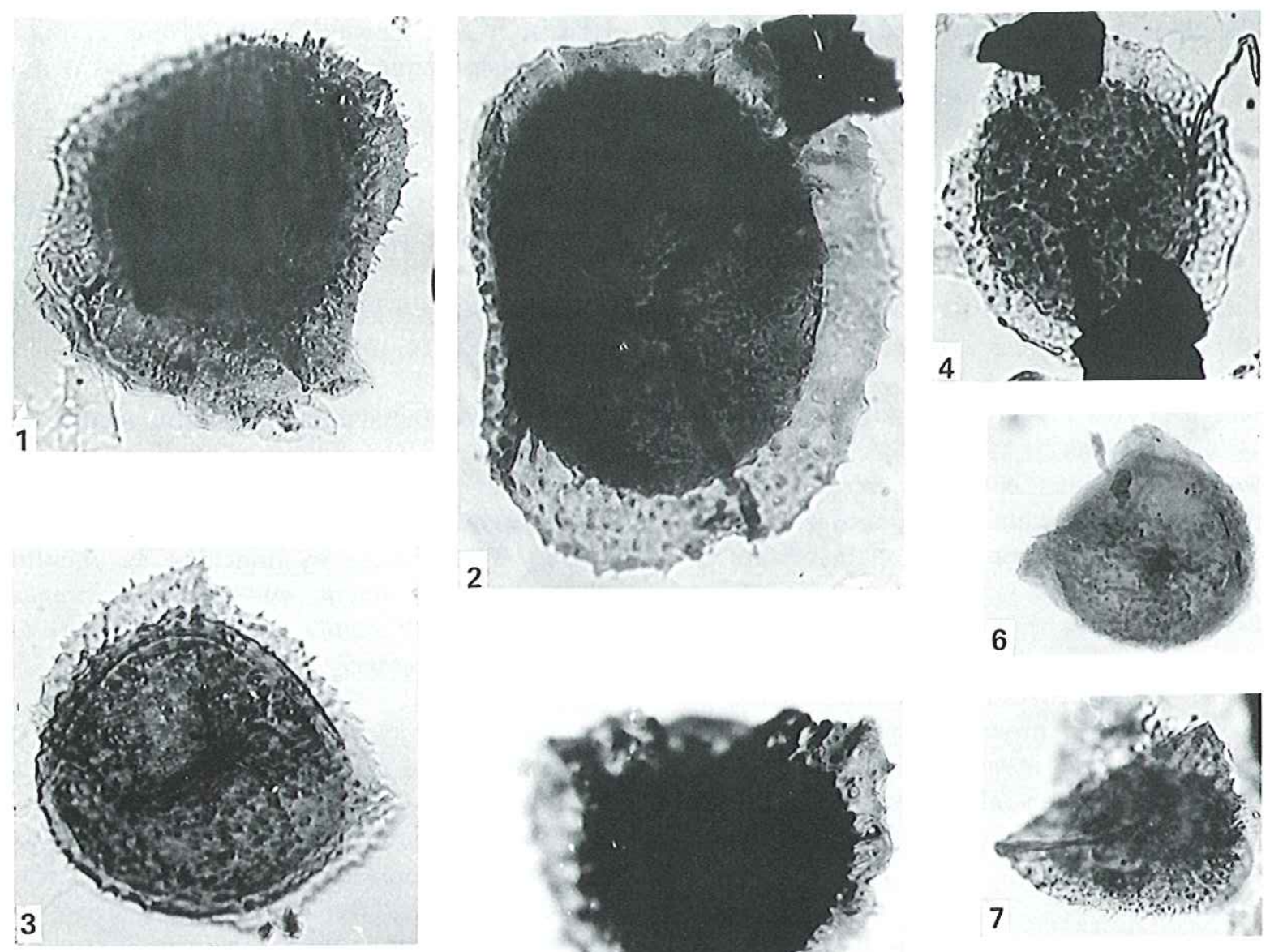

2
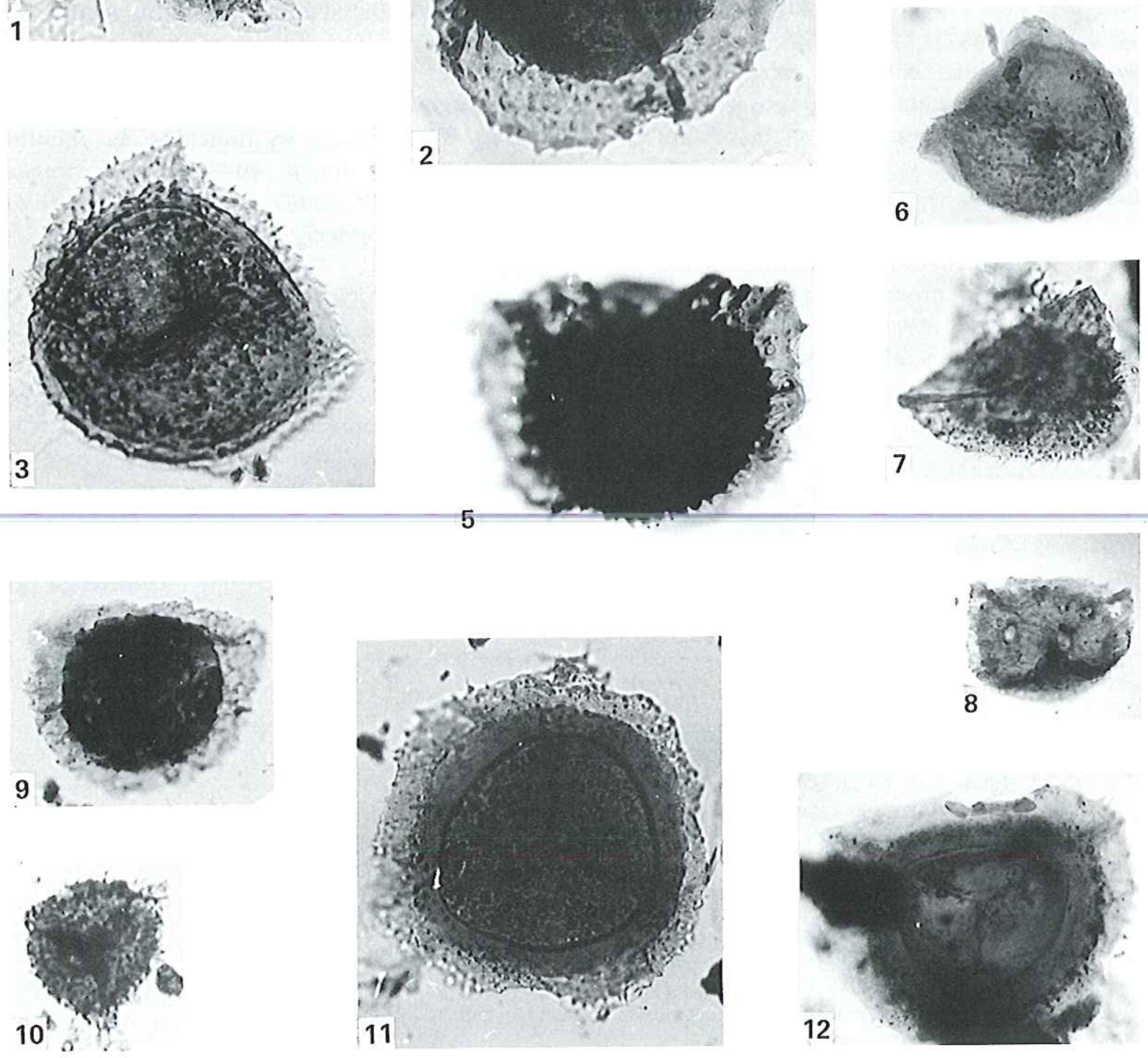

(for explanation see p.187) 
PLATE V
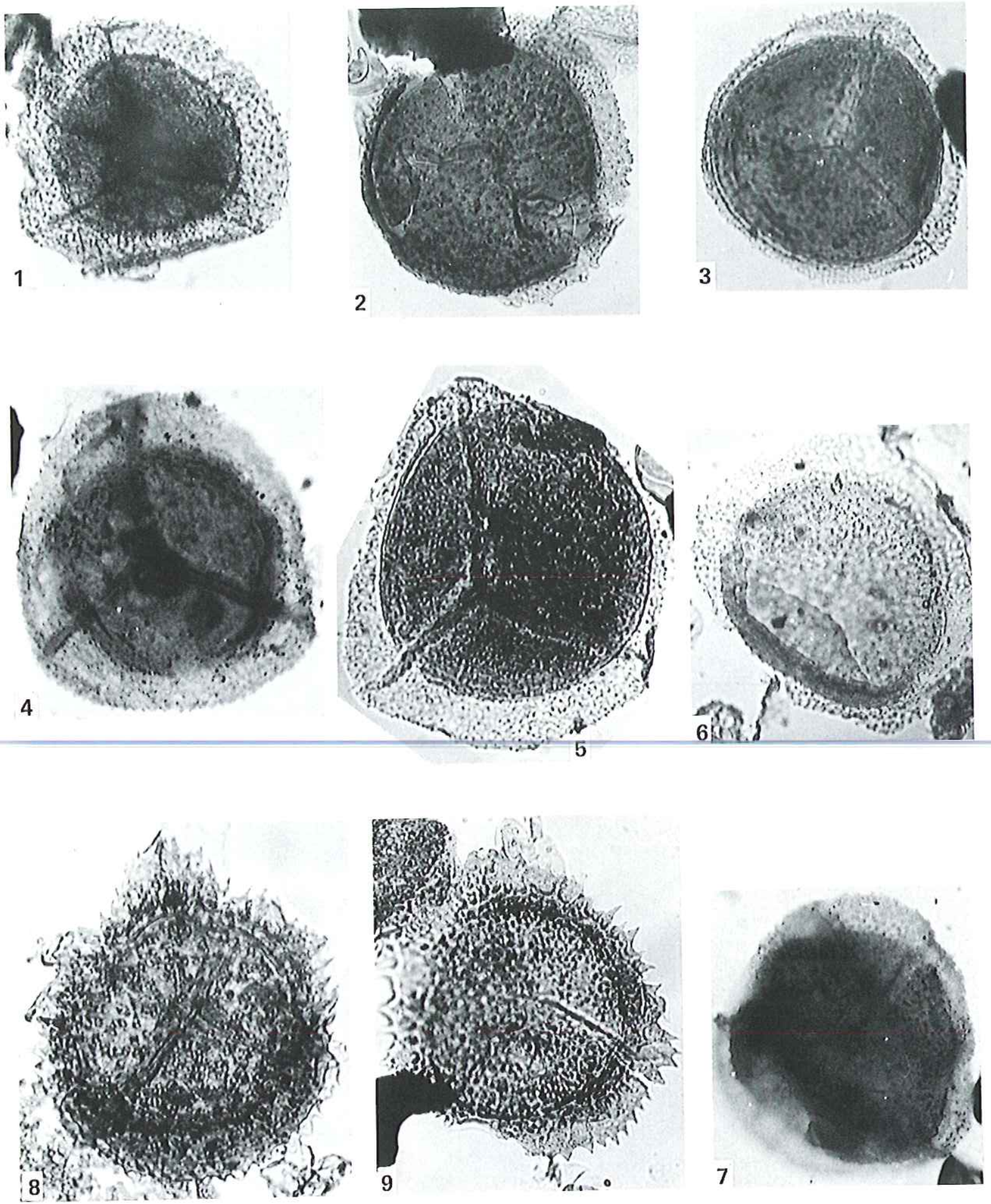

(for explanation see p.187) 


\section{PLATE VI}
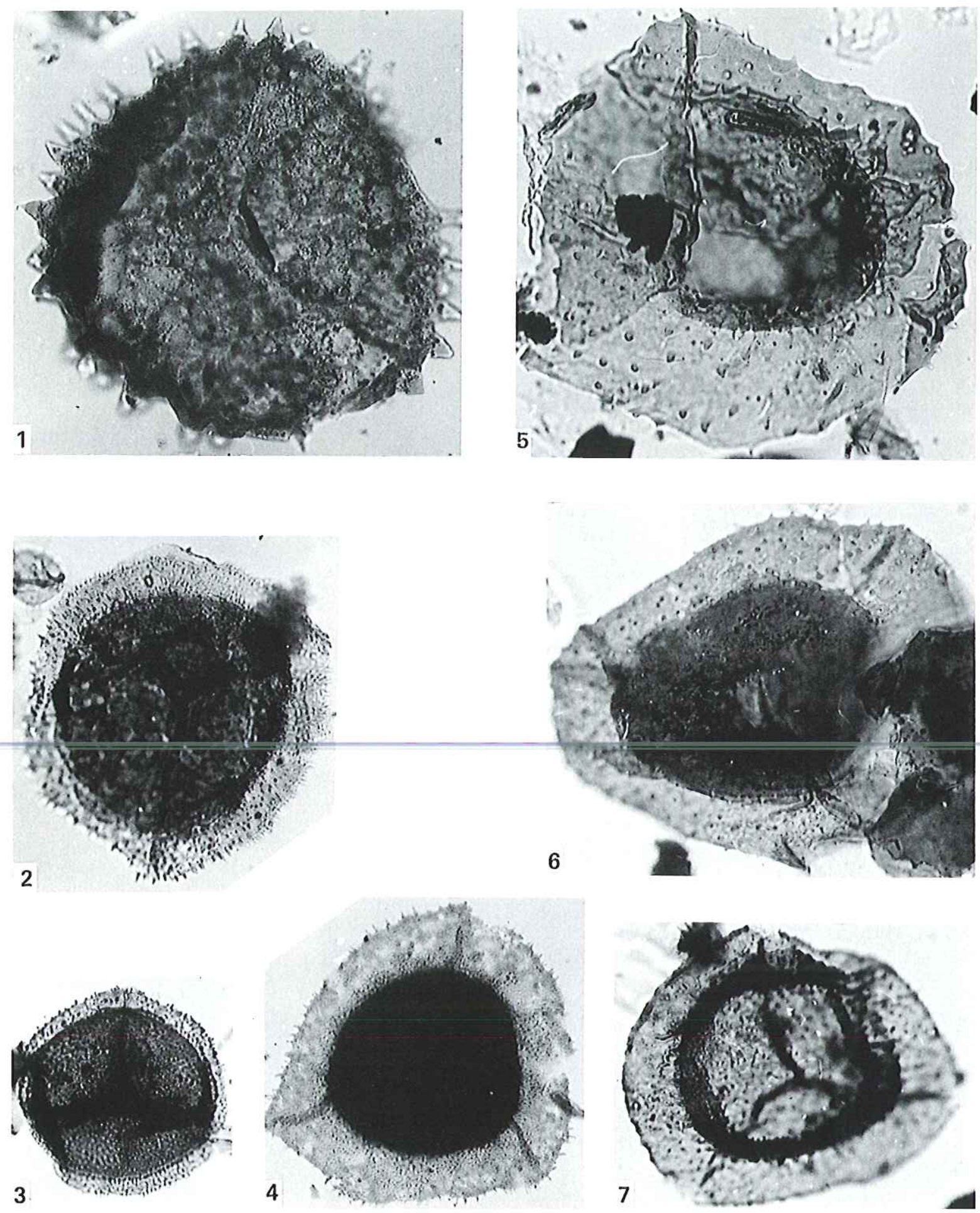

(for explanation see p.187) 
PLATE VII
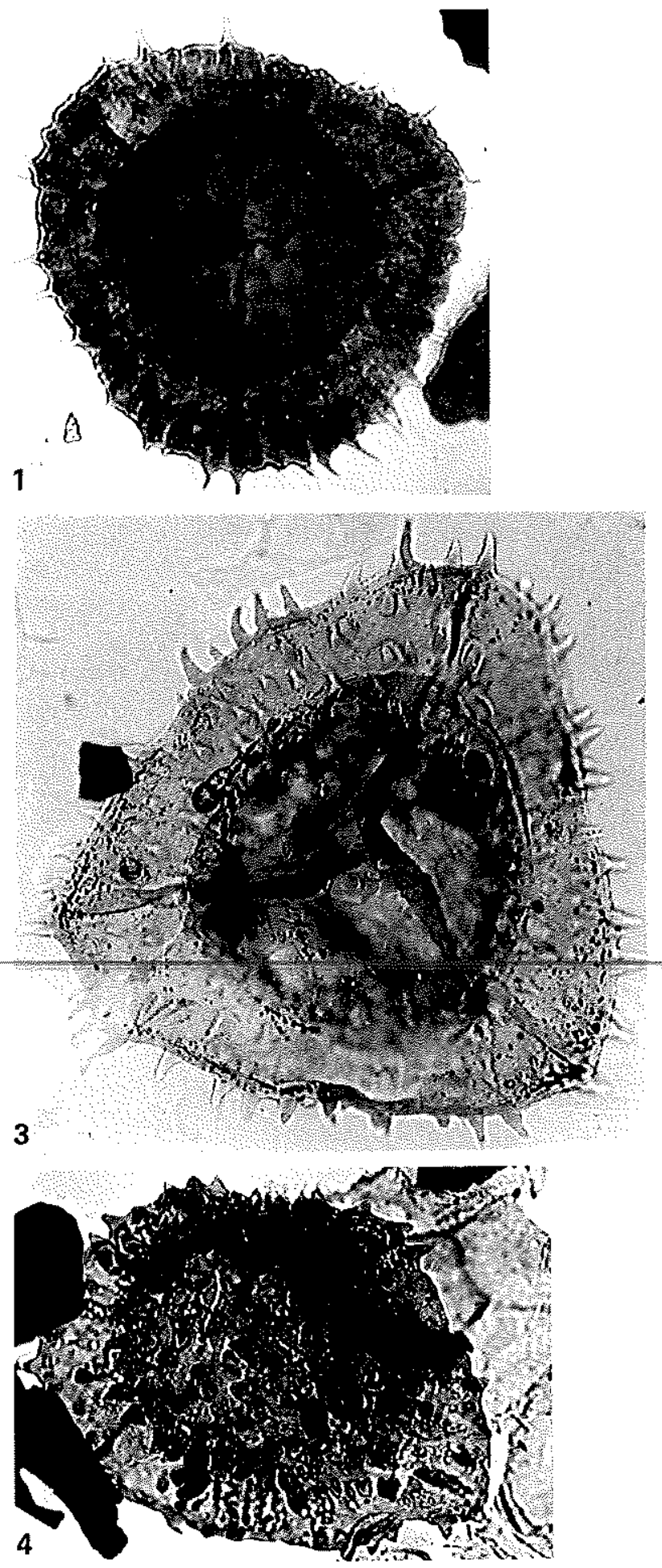

(for explanation see p.187)
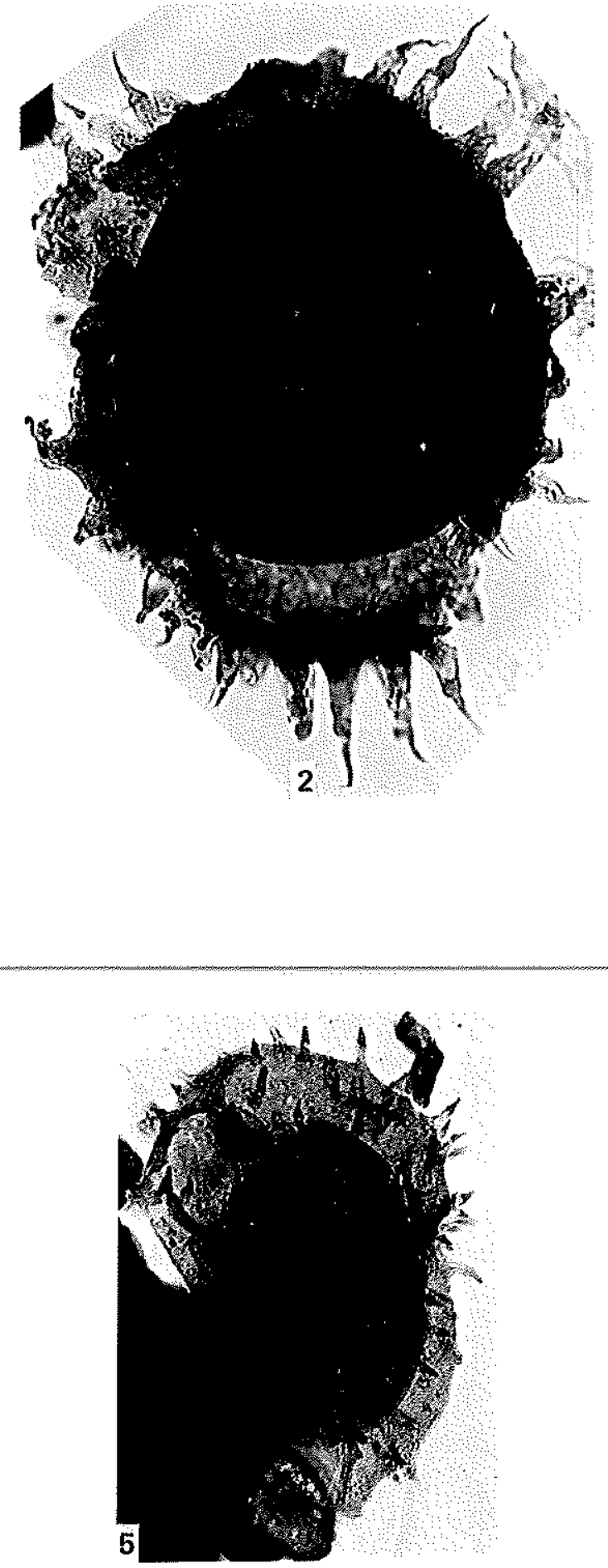
PLATE VIII
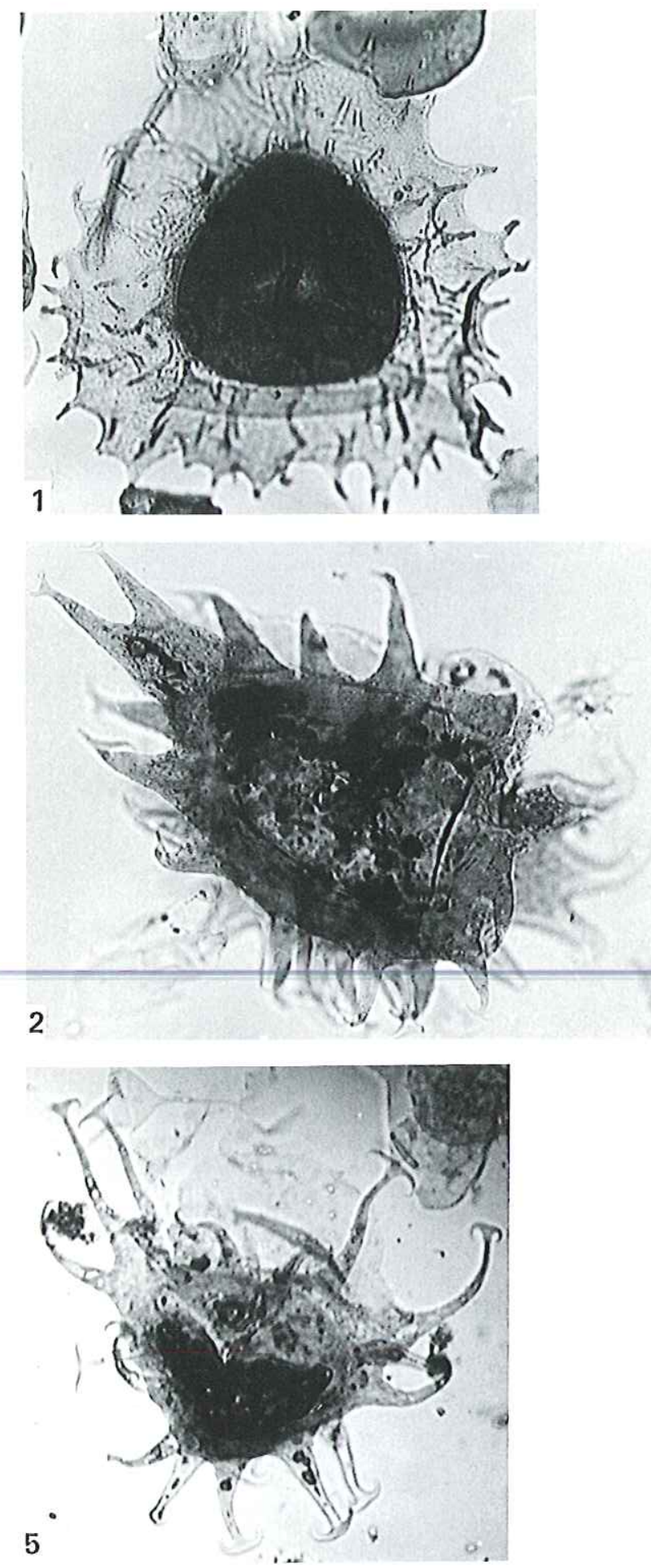
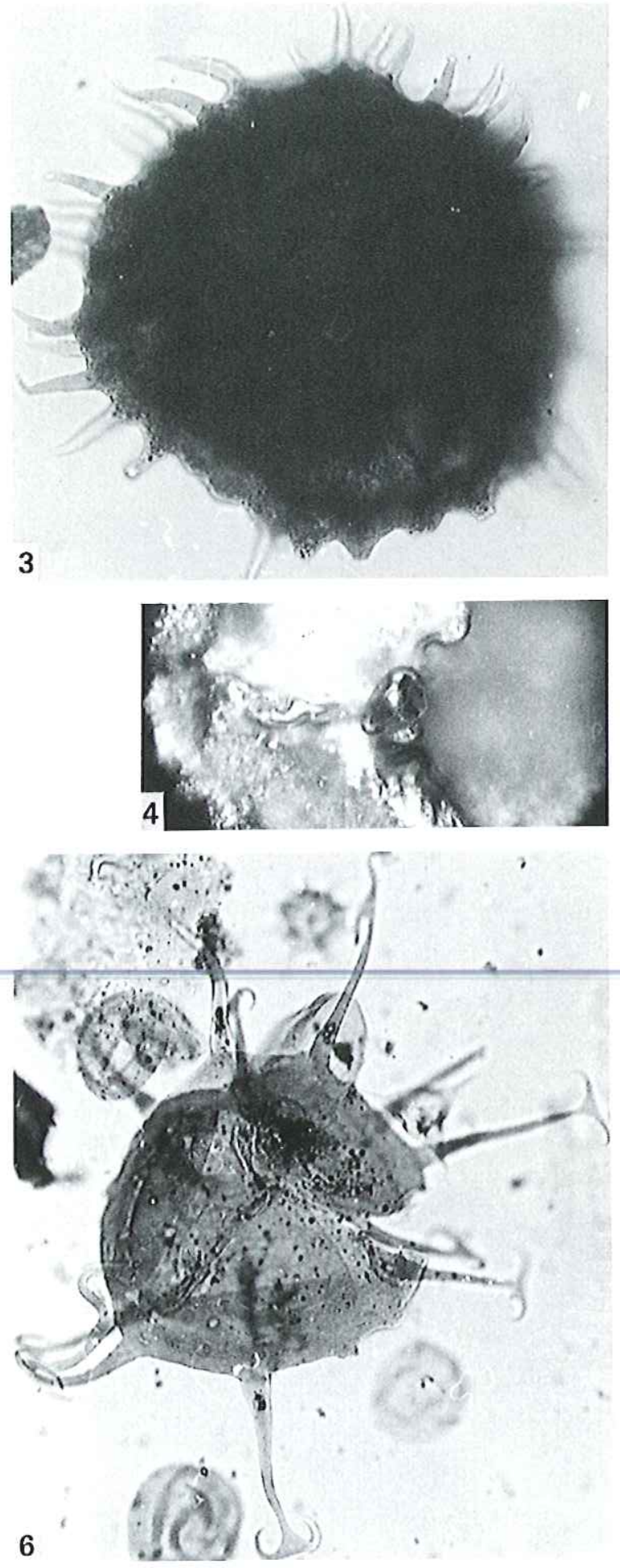
PLATE IV (see p.182)

All photographs $\times 500$

1-4. Samarisporites eximius (Allen) nov. comb.

1, $\mathrm{A}_{1}-69$, slide 1874(1): E34 ${ }^{3} .2, \mathrm{C}_{1}-49$, slide 2753(1): M32. 3, $\mathrm{A}_{1}-69$, slide 1322(1): R31. 4, $\mathrm{A}_{1}-69$, slide $1870(1): \mathrm{K} 47^{1}$.

5. Samarisporites praetervisus (Naumova) Allen 1965

$\mathrm{C}_{1} \cdot 49$, slide $2753(3):{\mathrm{L} 33^{2}}^{2}$.

6-8. Samarisporites triangulatus Allen 1965

6, $\mathrm{A}_{1} \cdot 69$, slide $1277(1): \mathrm{G} 24^{4} \cdot 7, \mathrm{~A}_{1} \cdot 69$, slide $976(2): \mathrm{R} 42^{3} \cdot 8, \mathrm{D}_{1} \cdot 26$, slide $2764(1): \mathrm{Q} 37^{2}$.

9. Samarisporites sp. E in Streel and Loboziak 1987

$\mathrm{D}_{1} \cdot 26$, slide $2764(2): \mathrm{O}_{40}{ }^{3}$.

10. Samarisporites sp. A in Loboziak and Streel 1981

$\mathrm{D}_{1}-26$, slide $2764(2): \mathrm{V} 25^{3}$.

11, 12. Densosporites devonicus Richardson 1960

11, $\mathrm{A}_{1} \cdot 69$, slide 1874(1) : P36 ${ }^{3} .12$, MG1, slide 2775(1) : H30.

PLATE V (see p.183)

All photographs $\times 500$

1-5. Grandispora riegelii nov. sp.

1, $A_{1} \cdot 69$, slide 1322(1): V51. 2, $\mathrm{A}_{1}-69$, slide 1596(1): M36. 3, $\mathrm{A}_{1} \cdot 69$, slide 1416(1):S28 ${ }^{1}$. 4, Holotype, MG1, slide 2760(1): R332 . 5, MG1, slide 2775(1): H37.

6, 7. Grandispora inculta Allen 1965

6, MG1, slide 2760(1): V27 ${ }^{1}$. 7, $\mathrm{A}_{1} \cdot 69$, slide $1310(1): \mathrm{N}^{4} 9^{4}$.

8, 9. Samarisporites angulatus (Tiwari and Schaarschmidt) nov. comb.

8, $\mathrm{A}_{1}-69$, slide $1867(1): \mathrm{P} 46^{1} .9, \mathrm{~A}_{1} \cdot 69$, slide $1867(1): \mathrm{V} 30^{3}$.

PLATE VI (see p.184)

All photographs $\times 500$

1. Grandiflora cassidea (Owens 1971) Moreau-Benoit 1976

MG1, slide 2775(1): Q36 4 .

2-4. Grandispora gabesensis nov. sp.

2, Holotype, $\mathrm{A}_{1} \cdot 69$, slide $1596(1): \mathrm{X} 30^{1} .3, \mathrm{~A}_{1} \cdot 69$, slide $1700(1): 032.4, \mathrm{~A}_{1} \cdot 69$, slide $1700(2): \mathrm{Q} 34^{2}$.

5, 6. Grandispora protea (Naumova) Moreau-Benoit 1980

5, $\mathrm{A}_{1} \cdot 69$, slide $1874(2): \mathrm{G} 21.6, \mathrm{~A}_{1} \cdot 69$, slide 2039(2) : R25 2 .

7. Grandispora velata (Eisenack) McGregor 1973

$\mathrm{C}_{1} \cdot 49$, slide $2753(3):$ L. $34^{3}$.

PLATE VII (see p.185)

All photographs $\times 500$

1. Grandispora incognita (Kedo) McGregor and Camfield 1976

$\mathrm{A}_{1}-69$, slide $1596(1)$ : U28 ${ }^{3}$.

2. Grandispora naumovii (Kedo) McGregor 1973

$\mathrm{A}_{1} \cdot 69$, slide $1700(1): \mathrm{X} 33^{1}$.

3. Grandispora libyensis Moreau-Benoît 1980

$\mathrm{A}_{1} \cdot 69$, slide $1310(1)$ : D $39^{3}$.

4. Grandispora megaformis (Richardson) McGregor 1973

$\mathrm{A}_{1}-69$, slide $1870(1): \mathrm{N} 38^{3}$.

5. Grandispora douglastownense McGregor 1973

$\mathrm{A}_{1} \cdot 69$, slide $1550(2): \mathrm{J}^{3} 5^{3}$.

\section{PLATE VIII}

All photographs $\times 500$

1. Ancyrospora nettersheimensis Riegel 1973

$\mathrm{A}_{1}-69$, slide 1700(1): J34.

2. Ancyrospora langii (Taugourdeau-Lantz) Allen 1965

$\mathrm{A}_{1} \cdot 69$, slide $976(1): \mathrm{Y}_{2} 4^{3}$.

3, 4. Hystricosporites mitratus Allen 1965

A, -69 , slide 1373(1): O42.

5, 6. Hystricosporites blessii nov. sp.

5, Holotype, $A_{1}-69$, slide $650(2)$ : H22. 6, $A_{1}-69$, slide $650(2)$ : H35. 
PLATE IX
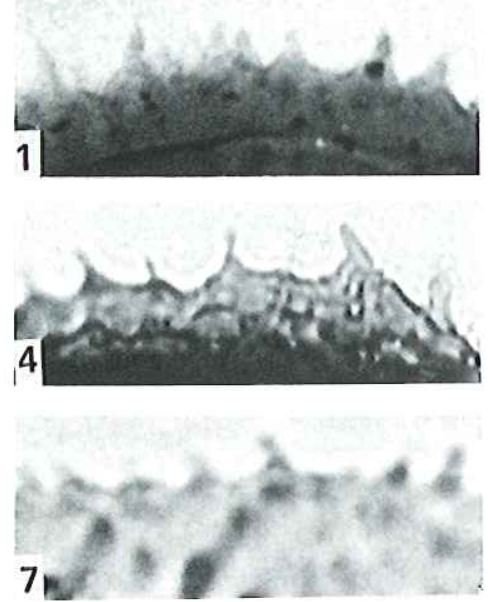

10 in

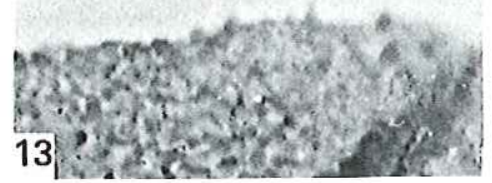

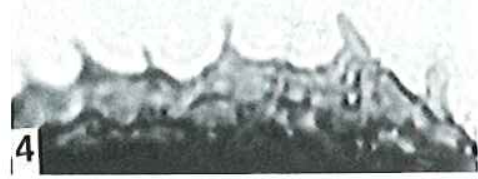
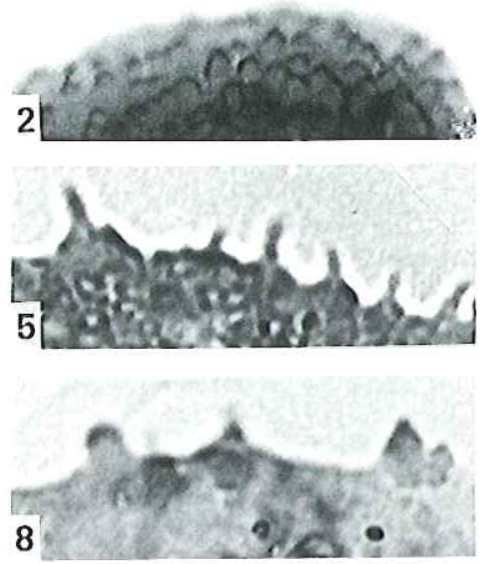

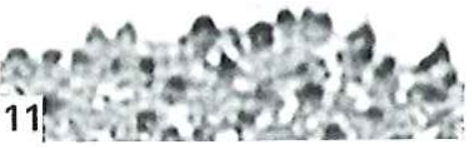

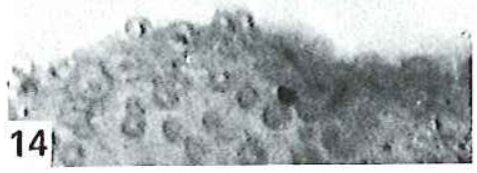

ing 16ters os

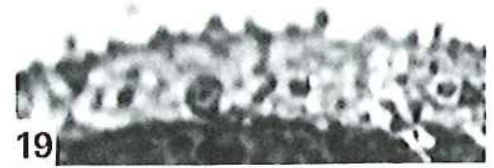
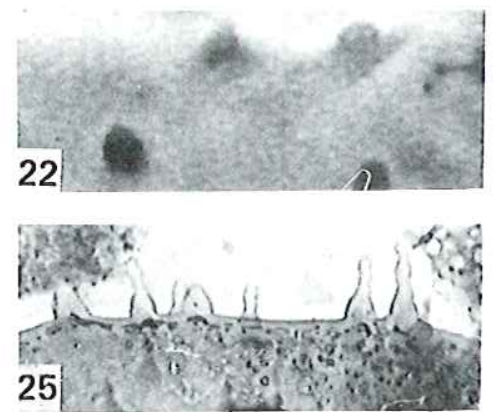

20.
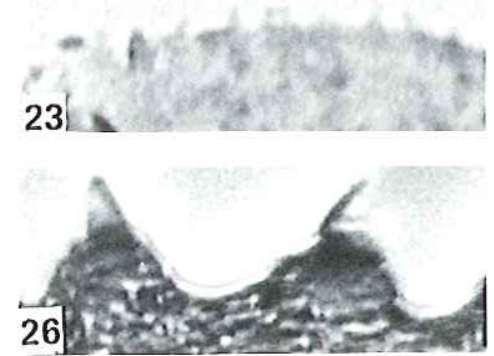
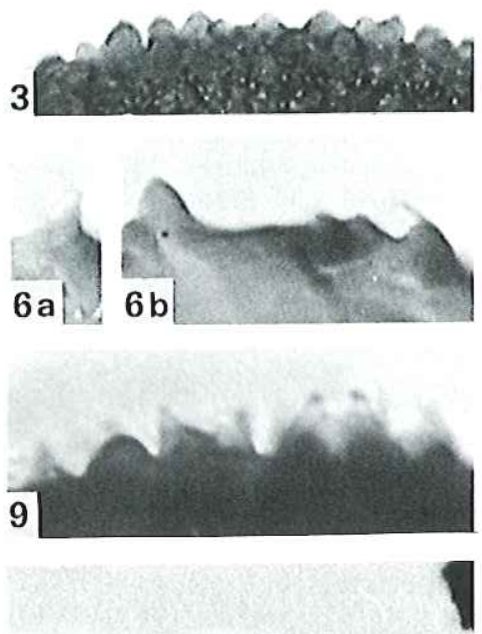

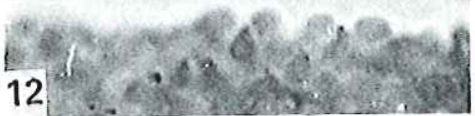

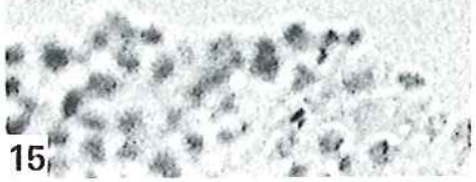

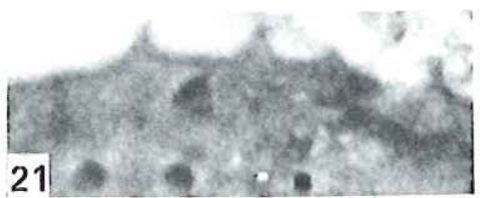

$24 \mathrm{a}_{\mathrm{a}} \mathrm{x}$ in $>24 \mathrm{~b}$.
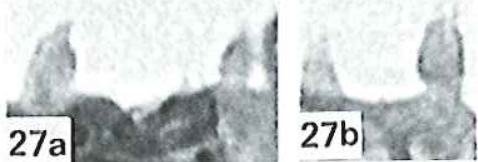
Siegenian spores around the Old Red Sandstone Continent (Richardson and McGregor, 1986; Streel et al., 1987). As the Siegenian age of the "Schistes bleus" cannot be challenged, we have to conclude the possibility of laboratory contamination of this assemblage. However, we have no reason to reject the new name given by Moreau-Benoit, 1980. It should however be emphasized that, with the exception of the Anjou material, all the specimens listed in synonymy by Moreau-Benoit 1980, p.33 are of Gondwanan origin if we reject Spinozonotriletes multispinosus Lanninger 1968 which obviously belongs to a different species.

Grandispora megaformis (Richardson) McGregor 1973 (Plate VII, 4 and Plate IX, 16)

Grandispora naumovii (Kedo) McGregor 1973 (Plate VII, 2)

\section{PLATE IX}

All photographs $\times 1800$

1. Acinosporites lindlarensis Riegel 1968

Detail of the Plate II, 5.

2. Cymbosporites catillus Allen 1965

Detail of the Plate II, 11.

3. Cymbosporites cyathus Allen 1965

Detail of the Plate II, 12.

4. Craspedispora ghadamisensis nov. sp.

Detail of the Plate II, 1, 2.

5-7. Samarisporites eximius (Allen) nov, comb.

5, Detail of the Plate IV, 1.

6, Detail of the Plate IV, 2.

7 , Detail of the Plate IV, 3.

8, 9. Samarisporites praetervisus (Naumova) Allen 1965

Detail of the Plate IV, 5 .

10-13. Grandispora riegelii nov. sp.

10, Detail of the Plate V, 1.

11, Detail of the Plate V, 2.

12, Detail of the Plate V, 4.

13, Detail of the Plate V, 5.

14, 15. Grandispora inculta Allen 1965

14, Detail of the Plate V, 6.

15, Detail of the Plate V, 7.

16. Grandispora megaformis (Richardson) McGregor 1973

Detail of the Plate VII, 4.

17-20. Grandispora gabesensis nov. sp.

17, $\mathrm{A}_{1}-69$, slide $1700(1)$ : X32.

18, Detail of the Plate VI, 2.

19, Detail of the Plate VI, 3.

20, Detail of the Plate VI, 4.

21, 22. Grandispora protea (Naumova) Moreau-Benoit 1980

21, Detail of the Plate VI, 6.

22, Detail of the Plate VI, 5.

23. Grandispora velata (Eisenack) McGregor 1973

Detail of the Plate VI, 7.

24. Grandispora incognita (Kedo) McGregor and Camfield 1976

Detail of the Plate VII, 1.

25. Grandispora libyensis Moreau-Benoit 1980

$\mathrm{A}_{1} \cdot 69$, slide $1322(1): \mathrm{L}^{1} 0^{1}$.

26. Grandispora cassidea (Owens) Moreau-Benoit 1976

Detail of the Plate VI, 1.

27. Grandispora douglastownense McGregor 1973

$\mathrm{A}_{1} \cdot 69$, slide 2039(2): R41. 
Grandispora protea (Naumova) Moreau-Benoit 1980 (Plate VI, 5, 6 and Plate IX, 21, 22)

Grandispora riegelii sp. nov. (Plate V, 1-5 and Plate IX, 10-13)

1967: Calyptosporites sp. A in Daemon et al., p.114, plate 3, 31-34.

1967: Calyptosporites sp. B in Daemon et al., p.114, plate 3, 35-36.

1974: Calyptosporites sp. B in Bar and Riegel, plate 1, 13. 1980: Grandispora velata (Eisenack) McGregor in MoreauBenoit, plate 12, 3 .

1985: Grandispora macrotuberculata (Archangelskaya) McGregor in Massa and Moreau-Benoit, plate 1, 6.

1985: Grandispora sp. A Riegel in Paris et al., plate 24, 8, 9. 1985: Grandispora sp. B Riegel in Paris et al., plate 24, 10. 1987: Grandispora sp. A Riegel in Schrank, plate 1,11.

Holotype: Plate V, 4 and Plate IX, 12, borehole MG1, slide 2760(1) : R332 .

Diagnosis: Trilete, camerate miospores with subtriangular to roundly triangular amb. Intexinal body conformable to or slightly more circular than the exoexinal amb. Laesura arms straight, up to $6 \mu \mathrm{m}$ high, generally reaching the equator. Intexine laevigate, sometimes with arcuate folds near the margin. Exoexine thinner than intexine, laevigate in contact areas, sculptured proximo-equatorially and distally with dominant mammillate and biform conical elements, but also grana, verrucae and coni, $1-3 \mu \mathrm{m}$ wide and high, irregularly distributed, sometimes closely spaced.

Diameter: $80-120 \mu \mathrm{m}$, mean $=96 \mu \mathrm{m}$ (30 specimens)

Diameter of intexinal body: $60-89 \%$ (commonly $79 \%$ ) of total spore diameter.

Derivation of name: After the name of the German palynologist Walter Riegel.

Comparison: Grandispora inculta Allen 1965 is smaller and bears only coni. G. inculta Allen 1965 in McGregor and Camfield 1982, p.45, textfig.66, pl.11,2, has a similar ornament to $G$. riegelii but these elements are more spaced, commonly 1-2 $\mu \mathrm{m}$ apart.

Occurrence: $\mathrm{AD}$ pre Lem-TCo Zones=Eifelian to early Frasnian.

Brazil: D3-D5, Parana Basin: Tibagi and Sao
Domingos Members, Lower Amazonas Basin: Erere and Curua Formations.

Ghana: shales of Accra.

Cyrenaica: borehole E1-82

Western desert near the Libyan-Egyptian border: Foram-1 well, at $2490 \mathrm{~m}$.

\section{Grandispora tomentosa Taugourdeau-Lantz 1957}

Grandispora velata (Eisenack) McGregor 1973 (Plate VI, 7 and Plate IX, 23)

\section{Genus Hystricosporites McGregor 1960}

Hystricosporites blessii sp. nov. (Plate VIII, 5, 6) 1974: Hystricosporites sp. A Streel in Becker et al., p.27, pl.22, 3-5.

1987: Hystricosporites sp. A in Streel and Loboziak p.101.

Holotype: Plate VIII, 5, borehole A1-69, slide 650(2) : H22.

Diagnosis: Trilete, camerate miospores with rounded amb. Laesura arms with flexous folds which may form an apical prominence (up to $35 \mu \mathrm{m}$ high). Intexinal body, laevigate, thin, often folded. Exoexine thicker $(4 \mu \mathrm{m})$, with laevigate contact areas. Remaining parts of the exoexine bearing very long processes with bifurcate terminations $(32-54 \mu \mathrm{m})$. The processes may have a bulbous base $(6-13 \mu \mathrm{m})$, taper markedly in their lower part but are more or less parallel sided in their upper part $(2-4 \mu \mathrm{m})$. They expand (up to $10 \mu \mathrm{m}$ ) immediately below the bifurcate terminations (up to $20 \mu \mathrm{m})$.

Diameter: Maximum equatorial diameter excluding the projecting ornaments: $57-86 \mu \mathrm{m}$, mean $=76 \mu \mathrm{m}$ (10 specimens).

Derivation of name: after the name of the Dutch ostracodologist Martin J.M. Bless.

Comparison: All other Hystricosporites with bifurcate processes have smaller ratio:length of processes/diameter of the body.

Occurrence: BM-IV Zones=Frasnian. ?TAIV $=$ ?Givetian-Frasnian in the Booischot borehole in Belgium. 
Hystricosporites mitratus Allen 1965 (Plate VIII, $3,4)$

\section{Genus Lophozonotriletes (Naumova) Poto- nié 1956}

Lophozonotriletes media Taugourdeau-Lantz 1967 (Plate I, 20)

Lophozonotriletes bouckaertii sp. nov. (Plate I, 21-23)

Holotype: Plate I, 22, borehole A1-69, slide 650(1) : Q33 ${ }^{3}$.

Diagnosis: Trilete miospores with rounded amb. Laesura arms straight or slightly sinuous, up to $3 \mu \mathrm{m}$ high, reaching the inner side of the equatorial structure. Contact areas laevigate. Remainder of the surface bearing closely spaced, sometimes fused, verrucae. Low verrucae of irregular shape and size, up to $5 \mu \mathrm{m}$ wide, up to $2 \mu \mathrm{m}$ high, partly confluent at their bases, forming short rugulae. Such rugulae accentuate the thickness of the exine when seen at the equator.

Diameter: $44-64 \mu \mathrm{m}$, mean $=53 \mu \mathrm{m} \quad(7$ specimens).

Derivation of name: after the name of the Head of the Belgian Geological Survey, Jos Bouckaert.

Remarks: We use the Lophozonotriletes concept as emended by Van der Zwan, 1980.

Comparison: This species differs of other species of Lophozonotriletes by the high density and the variation in shape and size of its ornamentation.

Occurrence: Zone IV = late Frasnian.

Genus Retusotriletes Naumova 1953 emend. Streel 1964

Retusotriletes rugulatus Riegel 1973 (Plate I, 1)

\section{Genus Rhabdosporites Richardson 1960}

Rhabdosporites langii (Eisenack) Richardson 1960 (Plate III, 4)
Rhabdosporites minutus Tiwari and Schaarschmidt 1975 (Plate III, 5, 6)

Rhabdosporites parvulus Richardson 1965.

Genus Rugospora Neves and Owens 1966

Rugospora bricei sp. nov. (Plate III, 1,2)

1981: Rugospora cf. flexuosa (Juschko) Streel in Becker et al., 1974, in Loboziak and Streel, p.51, pl.1, 11.

1983: Rugospora cf. flexuosa (Juschko) Streel in Becker et al., 1974, in Loboziak et al., p. 177.

Holotype: Plate III, 1, 2, borehole A1-69, slide 650(1): Q38 ${ }^{3}$.

Diagnosis: Trilete miospores with subtriangular to roundly triangular amb. Laesura arms straight to slightly sinuous, up to $2 \mu \mathrm{m}$ high, reaching the equator. Wall more or less separated into two layers, at least on the distal side except near the equator, the outer layer partly attached to the inner layer. Surface of outer layer usually smooth, thickness indiscernable, presumably very thin. Folding results in a more or less rugulate condition of the spore. Distal rugulae (1-1.5 $\mu \mathrm{m}$ wide), randomly to rarely radially arranged.

Diameter: $32-54 \mu \mathrm{m}$, mean $=45 \mu \mathrm{m}$ (17 specimens).

Derivation of name: After the name of the French palaeontologist Denise Brice.

Comparison: Rugospora radiata (Kedo) Byvsheva 1985 syn.: $R$. flexuosa (Juschko) Streel in Becker et al., 1974, non $R$. flexuosa (Juschko) Byvsheva 1985, has thicker and longer rugulae, most commonly radially arranged, on the distoequatorial margin.

R. flexuosa (Juschko) Byvsheva 1985 which has narrow chaotically placed distal rugulae is based on poorly published material.

Occurrence: Zone IV=late Frasnian. Boulonnais: Zones IV and V=late Frasnian-early Famennian.

\section{Genus Samarisporites Richardson 1965}

Samarisporites (al. Calyptosporites) angulatus (Tiwari and Schaarschmidt) nov. comb. (Plate $\mathrm{V}, 8,9)$ 
Basionym: Calyptosporites angulatus Tiwari and Schaarschmidt 1975, Abh. Senckenberg Naturforsch. Ges. 534: 44; pl.27, fig.1.

Remarks: Type material from the Eifel area as well as our material clearly shows a structure with a thick (?acamerate) central area characteristic of Samarisporites.

Samarisporites (al. Perotrilites) eximius (Allen 1965) comb. nov. (Plate IV, 1-4 and Plate IX, $5-7)$

Basionym: Perotrilites eximius Allen 1965, Palaeontol. 8: 731; pl.102, figs.11-13.

Remarks: Sections made through the type material from Spitsbergen by Allen, 1965, clearly shows the distally thick structure of the central area, characteristic of Samarisporites.

Samarisporites praetervisus (Naumova) Allen 1965 (Plate IV, 5 and Plate IX, 8, 9)

Samarisporites triangulatus Allen 1965 (Plate IV, 6-8)

Samarisporites sp. A in Loboziak and Streel 1981 (Plate IV, 10)

Samarisporites sp. E in Streel and Loboziak 1987 (Plate IV, 9)

\section{Genus Synorisporites Richardson and Lister 1969}

Synorisporites libycus Richardson and Ioannides 1973 (Plate I, 10)

\section{Genus Verrucosisporites Ibrahim 1933 emend. Smith 1971}

Verrucosisporites bulliferus Richardson and McGregor 1986 (Plate I, 6)

Verrucosisporites premnus Richardson 1965 (Plate I, 7)
Verrucosisporites scurrus McGregor and Camfield 1982 (Plate I, 8, 9)

Verrucosisporites cf. uncatus Richardson 1965.

\section{Stratigraphic results on borehole A1-69}

The stratigraphic range of the most characteristic miospores in borehole A1-69 is given on the chart, Fig.2. On the right hand part of this figure, we have mentioned the species which were utilised to define the comparable biozonation in the Ardenne-Rhenish regions (Streel et al., 1987) that we use as a reference scale.

The first stratigraphically significant species which occurs at $2039 \mathrm{ft}(622 \mathrm{~m})$ is Grandispora protea. In the Ardenne-Rhenish zonation, this species marks the base of the Interval Zone AP Pro (apiculatus-proteus Oppel Zone, proteus Interval Zone).

This species is not present in the lowermost sample at $2103 \mathrm{ft}(641 \mathrm{~m})$ but this sample provided only a rather poor assemblage of spores. In the sample from $2039 \mathrm{ft}(622 \mathrm{~m})$, the coexistence of Camarozonotriletes sextantii and $G$. protea suggests that the basal part of zone AP Pro has been encountered.

In the lowermost sample at $2103 \mathrm{ft}(641 \mathrm{~m})$, the presence-of Emphanisporites-annulatus and $C$. sextantii and the absence of large apiculate and spinose zonate-pseudosaccate spores are comparable with the annulatus-sextantii Assemblage Zone of Richardson and McGregor 1986.

The entry of Densosporites devonicus and Acinosporites acanthomammillatus respectively in $1874 \mathrm{ft}(572 \mathrm{~m})$ and $1870 \mathrm{ft}(570 \mathrm{~m})$ marks the base of the Interval Zone AD Mac (Acanthomammillatus-devonicus Oppel Zone, macrospinosus Interval Zone). The true first appearance of Grandispora velata should prob. ably be searched for in the unsampled interval $1950 \mathrm{ft}(595 \mathrm{~m})-1874 \mathrm{ft}(572 \mathrm{~m})$.

Geminospora lemurata first occurs in the sample at $1480 \mathrm{ft}(451 \mathrm{~m})$. Geminospora punctata occurs below this level. Therefore the $1480 \mathrm{ft}$ (451 m) level should not be far from the base of the Interval Zone AD Lem (acantho 


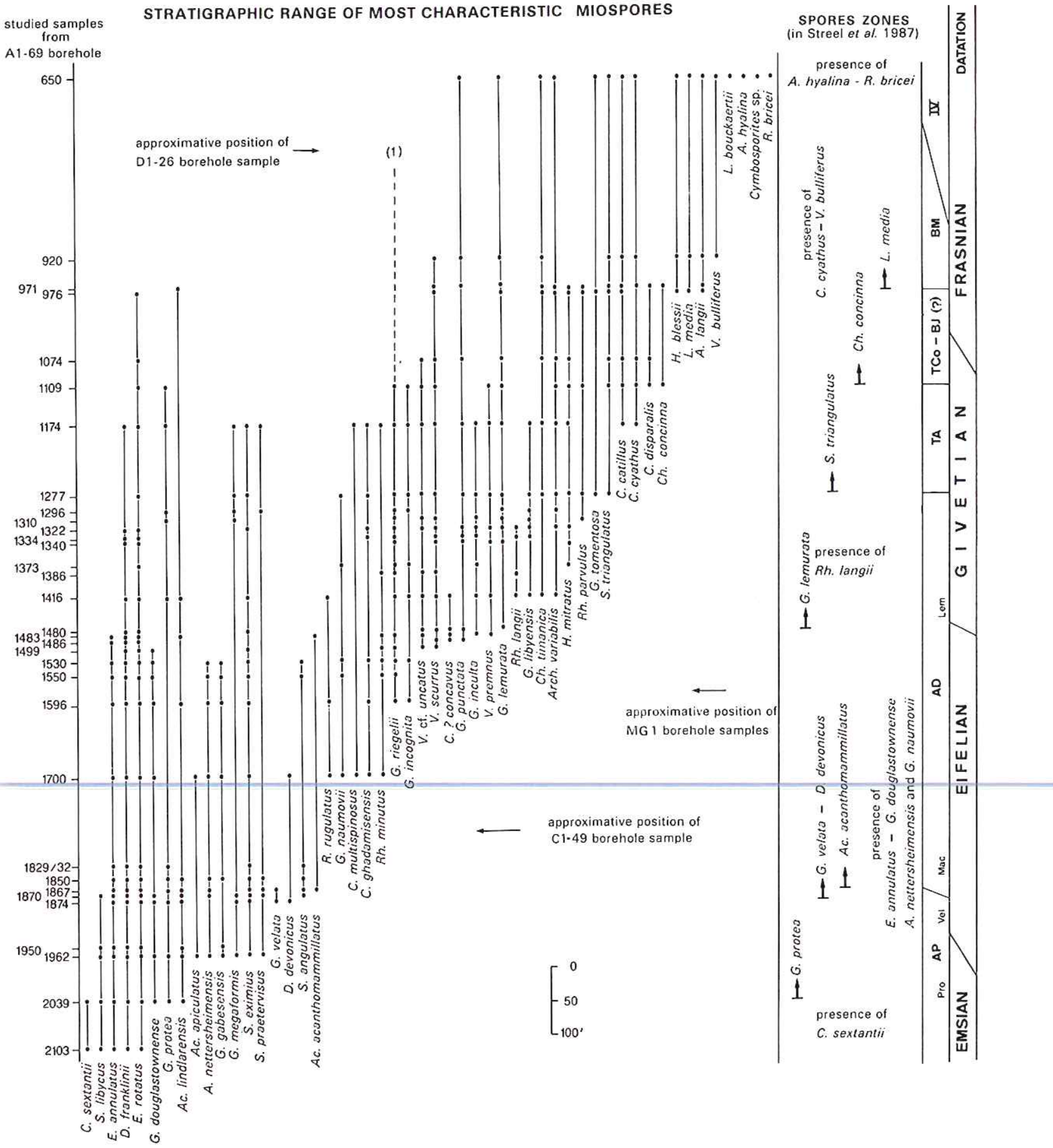

Fig.2. Stratigraphic range of the most characteristic miospores in borehole A1-69 and approximative stratigraphic position of samples studied in boreholes MG1 and C1-49.

(1) = Extension of $G$. riegelii in borehole D1-26 only. 
mammillatus-devonicus Oppel Zone, lemurata Interval Zone).

The successive first occurrences of Samarisporites triangulatus, Chelinospora concinna and Lophozonotriletes media correspond respectively to the bases of the Oppel Zones TA (triangulatus-ancyrea), TCo (Triangulatusconcinna) and BM (bulliferus-media). The lack of sample between $1074 \mathrm{ft}(328 \mathrm{~m})$ and $976 \mathrm{ft}$ $(298 \mathrm{~m})$ does not allow the recognition of the first occurrence of Verrucosisporites bulliferus which marks the base of the $\mathrm{BJ}$ (bulliferus-jekhowskyi) Oppel Zone in the Ardenne-Rhenish regions.

The uppermost sample at $650 \mathrm{ft}(198 \mathrm{~m})$ contains, amongst other miospores, Auroras. pora hyalina and Rugospora bricei (syn.: $R$. cf. flexuosa in Loboziak and Streel, 1981). Both species occur within Zone IV in the Boulonnais area in northern France (Loboziak et al., 1983). The lack of sample between $920 \mathrm{ft}(281 \mathrm{~m})$ and $650 \mathrm{ft}(198 \mathrm{~m})$ prevents us to locate the base of that Zone (IV) in the borehole A1-69.

In this borehole, the first occurences of the characteristic species are distributed in the same stratigraphic sequence as in the Ardenne--Rhenish reference biozonation. As no other biostratigraphic data nor any lithostratigraphic correlation are available in this borehole, we have-noreason to ehallenge the geological ages deduced from this biozonation. The section ranges from the Emsian to the late Frasnian and there is no miospore evidence for the presence of the Famennian Stage in the uppermost part of the borehole.

The base of the Eifelian Stage in the type area of the Eifel occurs between the entry of Grandispora protea and the entry of G. velata. In this borehole A1-69, the base of the Eifelian Stage is somewhere between $2030 \mathrm{ft}(619 \mathrm{~m})$ and $1874 \mathrm{ft}(572 \mathrm{~m})$.

There is as yet no internationally accepted position for the base of the Givetian. Most of the proposals however are within the range of the conodont ensensis zone. Spores are not known in the classic region of Givet in the Ardenne due to adverse sedimentary conditions. However, in the Eifel, spores are present.
Geminospora lemurata first occurs, in this region, within the ensensis zone which implies not far from the proposed bases of the Givetian stage.

In the borehole A1-69, G. lemurata occurs in sample $1480 \mathrm{ft}(451 \mathrm{~m})$.

The range of the TCo zone spans the base of the Frasnian stage in the Ardenne (Streel et al., 1987) and the stage boundary cannot therefore be defined accurately using miospores. In this borehole A1-69, the Givetian/ Frasnian boundary is taken between $1109 \mathrm{ft}$ (338 $\mathrm{m})$ and $976 \mathrm{ft}(298 \mathrm{~m})$.

In conclusion, it appears that the Eifelian and early Givetian stages are represented in this borehole by a much thicker sequence of rocks than the Upper Devonian, a situation also matched in eastern Libya (Streel et al., 1988).

\section{Comparisons with the other boreholes}

\section{Borehole C1-49}

The sample at $1170 \mathrm{~m}$ carries Synorisporites libycus, Emphanisporites annulatus, Diatomozonotriletes franklinii, Emphanisporites rotatus, Grandispora protea, Acinosporites lindlarensis, Samarisporites eximius, S. praetervisus, Grandispora velata and Craspedispora ghadamisensis.

\section{Borehole MGl}

Samples at $2221 \mathrm{~m}, 2232.6 \mathrm{~m}$ and $2234 \mathrm{~m}$ carry Emphanisporites annulatus, Diatomozonotriletes franklinii, Emphanisporites rotatus, Samarisporites eximius, Acinosporites macrospinosus, Densosporites devonicus, Acinosporites acanthomammillatus, Grandispora riegelii, Verrucosisporites cf. uncatus, V. scurrus, Geminospora punctata, Grandispora inculta, Verrucosisporites premnus, Grandispora libyensis, Chelinospora timanica, Archaeozonotriletes variabilis and Grandispora cassidea. In the Eifel region, $V$. cf. uncatus first occurs about at the same level as Geminospora lemurata (Streel et al., 1987). 


\section{Borehole D1-26}

The sample at $7999 \mathrm{ft}(2440 \mathrm{~m})$ contains Grandispora riegelii, Samarisporites triangulatus, Samarisporites sp. A. in Loboziak and Streel, 1981 and Samarisporites sp. E in Streel and Loboziak, 1987. Samarisporites sp. A only occurs in Zone IV in the Boulonnais area (Loboziak et al., 1983, p.176).

These results allow comparisons to be drawn between the borehole A1-69 biostratigraphy and the limited number of samples from the three other boreholes. They are given on the chart (Fig.2). The samples from boreholes C1-49 and MG1 are Eifelian, the sample from borehole D1-26 is Frasnian.

If the samples investigated in the boreholes C1-49 and MG1 do really belong to the Awaynat Wanin Formation II and III (D.Massa, pers. commun., 1987), we have to conclude that these formations are there of Eifelian age.

A similar conclusion was also suggested by Streel et al. (1988, table 1) based only on a stratigraphical interpretation of the then published miospores in western Libya.

\section{Conclusions}

The study of 55 species of miospores (including 7 new species) taken from 4 boreholes of the Ghadamis Basin leads to the following conclusions:

(1) In borehole A1-69, the first occurrences of the characteristic miospores are distributed in the same stratigraphic sequence as in the Ardenne-Rhenish reference biozonation. Chronostratigraphic correlations made through this biozonation give an Emsian to late Frasnian age for the 33 samples studied between $2103 \mathrm{ft}(641 \mathrm{~m})$ and $650 \mathrm{ft}(198 \mathrm{~m})$ in this borehole.

(2) The Eifelian and early Givetian Stages are represented in this borehole by a much thicker sequence of rocks than the Upper Devonian, a situation also noticed in eastern Libya.

(3) The samples belonging to the Awaynat
Wanin Formations II and III in the boreholes C1-49 and MG1 are Eifelian.

The 55 species of miospores studied represent most of the species present in these assemblages. We have not taken into account laevigate and apiculate, sometimes retusoid, miospores where the lack of characteristic features does not permit specific determination. We have also neglected a few specimens which probably belong to new species but which were present in too small numbers.

From these 55 species almost $90 \%$ are also found in the Old Red Sandstone Continent. This remark is important as it shows that, since the Emsian at least, the respective position of Gondwanaland and Old Red Sandstone Continent have been close enough to allow the general exchange of terrestrial plants (see also Young, 1987).

\section{Acknowledgements}

We are grateful to $\mathrm{B}$. Owens for comments and corrections on this manuscript, to $\mathrm{M}$. Masson-Smal, M. Mezzatesta-Giraldo and W. Strouvens for technical assistance.

\section{References}

Abdesselam-Rouighi, F, 1986. Premiers résultats biostrati. graphiques (miospores, acritarches et chitinozoaires) concernant le Dévonien moyen et supérieur du Môle d'Ahara (Bassin d'Illizi, Algérie). Rev. Micropaléontol., 39(2): 87-92.

Allen, K., 1965. Lower and Middle Devonian spores of north and central Vestspitsberg. Palaeontology, 8(4): 280-297.

Bär, P. and Riegel, W., 1974. Les microflores des séries paléozoïques du Ghana (Afrique occidentale et leurs relations paléofloristiques. Sci. géol., Bull., 27, 1-2: 39-57.

Becker, G., Bless, M.J.M., Streel, M. and Thorez, J., 1974. Palynology and ostracod distribution in the Upper Devonian and basal Dinantian of Belgium and their dependence on sedimentary facies. Meded. Rijks Geol. Dienst, N.V., 25(2): 9-99.

Byvsheva, T.V., 1985. Spory iz otlozheny turneiskogo i vizeiskogo yarussov Russkoi plity. $\mathrm{V}$ kn.: Atlas spor i pyltsy neftegazonossnyh tolshch fanerozoya Russkoi i Turanskoi plit. Tr. VNIGNI, M.: Nedra, s. $80-158$, vyp. 253.

Chibrikova, E.V., 1959. Spores from the Devonian and other rocks of Bashkiria. In: Data on Paleontology and 
Stratigraphy of Devonian and Older deposits of Bashkiria. Acad. Sci. USSR, Bashkirian Branch. 3-116 (in Russian).

Chibrikova, E.V., 1962. Spores of Devonian terrigenous deposits of western Bashkiria and the western slopes of the southern Urals. In: Brachiopods, Ostracods and Spores of the Middle and Upper Devonian of Bashkiria. Acad. Sci. USSR, Bashkirian Branch, Inst. Min. Geol. 353-476 (in Russian).

Daemon, R.F., Quadros, L.P. and Da Silva, L.C., 1967. Devonian palynology and biostratigraphy of the Paraná basin. In: J.J. Bigarella (Editor), Problems in Brazilian Devonian Geology. Bol. Parana. Geocienc., 21/22: 99-132.

Kedo, G.I., 1955. Spores of the Middle Devonian of the northeastern Byelorussian SSR; Institute of Geological Sciences, Paleontology and Stratigraphy of BSSR, Stornik 1: 5-59 (in Russian).

Loboziak, S. and Streel, M., 1981. Miospores in MiddleUpper Frasnian to Famennian sediments partly dated by conodonts (Boulonnais, France). Rev. Palaeobot. Palynol., 34: 49-66.

Loboziak, S., Streel, M. and Vanguestaine, M., 1983. Miospores et acritarches de la Formation d'Hydrequent (Frasnien supérieur à Famennien inférieur, Boulonnais, France). Ann. Soc. Géol. Belg., 106: 173-183.

Massa, D. and Moreau-Benoit, A., 1976. Essai de synthèse stratigraphique et palynologique du système dévonien en Libye occidentale. Rev. Inst. Fr. Pet., 31(2): 287-333.

Massa, D. and Moreau-Benoit, A., 1985. Apport de nouvelles données palynologiques à la biostratigraphie et à la Paléogéographie du Dévonien en Libye (sud du Bassin de Rhadamès). Sci. Géol. Bull., 38(1): 5-18.

McGregor, D.C. and Camfield, M., 1976. Upper Silurian? to Middle Devonian spores of the Moose River Basin, Ontario. Geol. Surv. Can. Bull., 263, 63 pp.

McGregor, D.C. and Camfield, M., 1982. Middle Devonian miospores from the Cap de Bray, Weatherall and Hecla Bay Formations of northeast Melville Island, Canadian Arctic. Geol. Surv. Can. Bull., 348, 105 pp.

Moreau-Benoit, A., 1967. Premiers résultats d'une étude palynologique du Dévonien de la carrière des Fours à chaux d'Angers (Maine-et-Loire). Rev. Micropaléontol., 9(4): 219-240.

Moreau-Benoit, A., 1979. Les spores du Dévonien de Libye, 1ère partie. Cah. Micropaléontol., 4: 3-58.

Moreau-Benoit, A., 1980. Les spores du Dévonien de Libye, 2ème partie. Cah. Micropaléontol., 1: 3-53.

Moreau-Benoit, A., 1984. Acritarches et chitinozoaires du
Dévonien moyen et supérieur de Libye occidentale. Rev. Palaeobot. Palynol., 43: 187-216.

Naumova, S.N., 1953. Spore-pollen assemblages of the Russian platform and their stratigraphic significance. Trans. Inst. Geol. Sci. Acad. Sci. USSR, (Geol. ser., 60), 143, 204 pp. (in Russian).

Owens, B., 1971. Miospores from the Middle and early Upper Devonian rocks of the western Queen Elizabeth Islands, Arctic Archipelago. Geol. Surv. Can. Pap., 70-98, $157 \mathrm{pp}$.

Paris, F., Richardson, J.B., Riegel, W., Streel, M. and Vanguestaine, M., 1985. Devonian (Emsian-Famennian) Palynomorphs. J. Micropaleontol., 4(1): 49-81.

Richardson, J.B, and McGregor, D.C., 1986. Silurian and Devonian spore zones of the Old Red Sandstone Continent and adjacent regions. Geol. Surv. Can. Bull., 364, $79 \mathrm{pp}$.

Schrank, E., 1987. Palaeozoic and Mesozoic palynomorphs from northeast Africa (Egypt and Sudan) with special reference to Late Cretaceous pollen and Dinoflagellates. Berl. Geowiss. Abh., A, 75(1): 249-310.

Streel, M., Higgs, K., Loboziak, S., Riegel, W. and Steemans, P., 1987. Spore stratigraphy and correlation with faunas and floras in the type marine Devonian of the Ardenne-Rhenish regions. Rev. Palaeobot. Palynol., 50: 211-229.

Streel, M. and Loboziak, S., 1987. Nouvelle datation par miospore du Givétien-Frasnien des sédiments non marins du sondage de Booischot (Bassin de Campine, Belgique). Bull. Soc. Géol. Belgique, 96(2): 99-106.

Streel, M., Paris, F., Riegel, W. and Vanguestaine, M., 1988. Acritarch, chitinozoan and spore stratigraphy from the Middle and Upper Devonian subsurface of Northeast Libya. In: E. Arnautı, B. Owens et B. Thusu (Eds). Aspect of Northeast Libyan Biostratigraphy with emphasis on Palynomorphs. Gariounis Univ. Spec. Publ., in press.

Tiwari, R.S. and Schaarschmidt, T., 1975. Palynological studies in the Lower and Middle Devonian of the Prüm Synclines, Eifel (Germany). Abh. Senckenb. Naturforsch. Ges., 534: 1-129.

Van der Zwan, C.J. 1980. Aspects of late Devonian and early Carboniferous palynology of southern Ireland. III. Palynological Devonian-Carboniferous transition sequences with special reference to the Bantry Bay area, Co. Cork. Rev. Palaeobot. Palynol., 30: 265-286.

Young, G.C., 1987. Devonian palaeontological data and the Armorica problem. Palaeogeogr., Palaeoclimatol., Palaeoecol., 60: 283-304. 